Chapter 2

\title{
Use of Trace Elements and Halotherapy in the Treatment of Human Diseases
}

\author{
Vincent S. Gallicchio \\ Additional information is available at the end of the chapter \\ http://dx.doi.org/10.5772/58235
}

\section{Introduction}

Trace elements possess important therapeutic properties. First, binding to specific macromolecules (enzymes, nucleic acids, etc.) they influence important chemical and biological processes; second, they interact amongst themselves synergistically to amplify their individual reactions. Some trace elements are also metals. Not all metals are trace elements. Metals have been used therapeutically for hundreds of years. Use of metals in the treatment of human diseases began with discoveries with gold used initially in patients with tuberculosis followed by rheumatoid arthritis. Gold identified an immunological pathogenesis in the etiology of rheumatoid arthritis, thus metals may be efficacious in other human conditions that are immunological in etiology. The antineoplastic potential of metals was further disseminated by the development of less toxic compounds such as platinum. Third, use of metals in the treatment of human cancers has improved the therapeutic effectiveness response to this diverse group of diseases. Fourth, lithium use in clinical medicine revolutionized treating psychiatric mood disorders. Central to the biological action of lithium is its ability to influence brain and central nervous system chemistry, thereby providing spectacular results in the treatment of affective and other psychiatric mood disorders, in particular, suicide prevention. Discoveries defining alternative non-psychiatric clinical use of lithium continue to intrigue clinical medicine based upon a key discovery demonstrating lithium can effectively influence stem cells. Halotherapy is using salt compounds as initial and maintenance therapy of human respiratory aliments. Used by the Greeks and Romans, halotherapy has existed for thousand of years. It is associated with the therapeutic effectiveness attributed to spas. Today halotherapy has gained resurgence with its use as personalized medicine in the treatment of human diseases. 


\section{Trace elements as medicines}

\subsection{Role and function as medicine for the treatment of human diseases}

Trace element properties are the core of their therapeutic activity based upon their activity in chemical reactions such as binding to macromolecules like enzymes and nucleic acids, inhibiting specific biological reactions, and their interactions with other elements. These general properties, specifically the binding to large molecules are far from specific, which helps explain why their use has gained interest and popularity over the years in a wide range of diseases in which trace elements have been implicated as medicine. Although trace elements as metals have been associated with human use for centuries, the scientific basis for their use as medicines in humans began with the gold compounds, initially in patients with tuberculosis and later in rheumatoid arthritis. Although other drugs have been developed to treat these infectious and inflammatory diseases, gold has retained an important position in the treatment of these diseases especially in certain cultures. Gold-induced effects on the immune system in rheumatoid arthritis are observed in conditions where autoimmune is involved. Trace element metal complexes have been used as anti-cancer therapy. They have been widely used by the development of less toxic compounds such as platinum and possibly other trace elements. Simultaneously there have been improvements in the administration of these compounds. This increases their therapeutic efficacy in the treatment of specific diseases. There are specific types of cancers that respond to trace elements. The gastrointestinal system represents another area where trace elements have a therapeutic role both in the control of intraluminal acidity and nutrient availability. The central nervous system is another area for trace element therapeutics. This involves the use of lithium. Lithium has provided significant results in the treatment of affective, bi-polar and manic disorders. More recently lithium has shown the ability to influence stem cells derived from a number of different sites in the human body. Thus, lithium may also have clinical use in human alignments or injuries such as spinal chord conditions where here-to-fore these patients were committed to a lifetime of paralysis. An example is spinal chord injuries where lithium use with stem cells can improve clinical outcomes in these patients who previously were non-treatable. With a very wide range of other conditions in which they are employed, trace element use provides a compelling illustration of the importance of trace elements in human disease.

\subsection{Boron}

In the periodic table boron finds its place in group 13 comprising boron, aluminum, gallium, indium, thallium, and ununtrium. Boron group elements are characterized by having three electrons in their outer energy levels (valence layers) [1]. These elements have also been referred to as icosagens and triels [2].

Boron is classified as a metalloid. Boron occurs sparsely, probably because bombardment by the subatomic particles produced from natural radioactivity disrupts its nuclei. Aluminum occurs widely on earth, and is the third most abundant element in the Earth's crust (8.3\%)[3]. Gallium is abundant on earth, while Indium is the 61st most abundant element in the earth's 
crust. Thallium is found in moderate amounts. Ununtrium is never found in nature and therefore is termed a synthetic element.

Many of the elements found in this group have fundamental roles in biology. Boron is a trace element in humans and is also essential for some plants. Lack of boron can lead to stunted plant growth, while excess boron thus can cause harm by inhibiting growth. Aluminum has neither a biological role nor significant toxicity associated with it and is considered safe. Both indium and gallium can stimulate metabolism with gallium credited with the ability to bind to iron proteins; however, thallium is highly toxic interfering with numerous vital enzymes. When boron was used as a pesticide it contributed to these effects [4].

Boron is a very light element because of its atomic number of five. In nature it is almost never found free thus it is very low in abundance, comprising only $0.001 \%$ (10 ppm)[5] of the Earth's crust. It is known to occur in over a hundred different minerals and ores; however, the main source is borax, but it is also found in complex compounds [6]. Areas in the world that mine boron include Argentina, Bolivia, China, Peru, Turkey and the United States. Turkey is by far the most important accounting for around $70 \%$ of all boron extracted in the world. For the United States it is the state of California that engages in significant production [7].

Boron is essential for many plants. Plant cells use it for strengthening cell walls. It is classified as a trace element in humans, but there is debate over its significance in human nutrition. The chemistry of boron allows it to form carbohydrate complexes so its role in nutrition in the human body may be more important than previously thought. Boron has also been shown to replace iron in some of its functions, particularly in wound healing [8]. Aluminum has no known biological role in animals or plants. Gallium is not essential for the human body, but it does interact with iron that allows it to become bound to iron bound and transport proteins [9]. Gallium can also stimulate metabolism. Indium and its heavier complexes have no known biological role, although in small amounts like gallium, indium salts can stimulate metabolism [10].

All elements within the boron group can be toxic. Many are only toxic to plants, some only to animals with some to both. An example of boron toxicity is it harms barley in concentrations exceeding $20 \mathrm{mM}$ [11]. In plants the symptoms of boron toxicity are numerous, such as: reduced cell division, decreased shoot and root growth, decreased production of leaf chlorophyll, inhibition of photosynthesis, lowering of stomata conductance, reduced proton extrusion from roots, and deposition of lignin and sub-origin [12].

In human medicine, boron is found in the form of boric acid, which is used as a topical astringent and as an ophthalmologic irrigant. Sodium borate is bacteriostatic and commonly added to cold creams, washes, and mouth rinses. Boron compounds found in over-the-counter supplements are reported to enhance mental attentiveness from studies that found alterations in the electroencephalogram in the presence of a low-boron diet. These studies reported also that there's a correlation between a low-boron diet and a decrease in mental alertness. There is no evidence however, that diet supplementations of boron compounds, above the levels derived from a normal balanced diet can enhance mental acuity or improve alertness. When 
sprinkled in crevices and corners, boric acid powder controls rodents and insects. Boron compounds are used to enhance the cytotoxicity associated with the use of radiation therapy.

\subsection{Calcium}

Calcium (Ca) with the atomic number of 20 is a soft gray alkaline earth metal that is the $5^{\text {th }}$ most abundant element by mass found in the earth. Calcium is also the fifth-most-abundant dissolved ion both molarity and mass in seawater, following sodium, chloride, magnesium, and sulfate [13]. For living organisms calcium is essential, in particular where movement of the cytoplasmic calcium ion $\mathrm{Ca}^{2+}$ into and out of functions as a signal for many cellular processes.

Calcium salts are colorless. As with magnesium salts and other alkaline earth metal salts, calcium salts are often quite soluble in water. Notable exceptions include the hydroxides such as the sulfates, carbonates and phosphates. When in solution, the calcium ion to the human taste varies remarkably, being reported as mildly salty, sour, "mineral like" or even "soothing." It is apparent that many animals can taste, or develop a taste, for calcium, and use this sense to detect the mineral in a variety of locations and sources [14]. In human nutrition, soluble calcium salts may be added to tart juices without much effect to the average palate.

Calcium is the fifth-most-abundant element by mass in the human body, where it is a common cellular ionic messenger with many functions like enzymes. It also serves as a structural element in bone. It has a relatively high atomic number. Calcium in the skeleton causes bone to be radio-opaque. The human body's solid components following drying or burning of organics, as an example observed following cremation, contributes to about a third of the total "mineral" mass remaining in the body. Approximately one kilogram of calcium is composed in the average skeleton with the remaining mineral content being composed of mostly phosphorus and oxygen.

Calcium should be a very important component of the human diet and is a mineral necessary for life. The National Osteoporosis Foundation states that calcium should play an important role in building stronger, denser bones both early in life and in keeping bones strong and healthy later in adulthood. Approximately 99 percent of the body's calcium is stored in the bones and teeth [15]. In the body calcium has other important uses such as in exocytosis, specifically in neurotransmitter release, and muscle contraction. In the electrical system of the heart, calcium replaces sodium as the mineral that depolarizes the cell, proliferating the action potential. In cardiac muscle, sodium influx initiates an action potential, but during the efflux of potassium, the cardiac myocyte experiences calcium influx, prolonging the action potential and creating a plateau phase of dynamic equilibrium. Long-term deficiency of calcium can lead to rickets and poor blood clotting and in menopausal women it can lead to osteoporosis, where the bone deteriorates creating an increased risk of fractures. While lifelong calcium deficits can affect bone and tooth formation, over-retention causes an increase in blood calcium called hypercalcemia, impaired kidney function and decreased absorption of other minerals $[16,17]$. Sources suggest there's a correlation between high calcium intake (2000 mg per day, or twice the U.S. recommended daily allowance, equivalent to six or more glasses of milk per day) and prostate cancer [18]. High calcium intakes or absorption were previously thought to 
contribute to the development of kidney stones; however, high calcium intake has been associated with a lower risk for kidney stones in more recent research [19-21], because Vitamin $\mathrm{D}$ is required to absorb calcium.

Milk and cheese as dairy products are well-known sources of calcium. Some individuals are allergic to dairy products. There are people who are lactose-intolerant leaving them unable to consume non-fermented dairy products in quantities larger than about half a liter per serving. Others, especially vegans avoid dairy products for ethical and health reasons.

Many good vegetable sources of calcium exist as in seaweeds such as kelp, wakame, and hijiki; nuts and seeds like almonds, hazelnuts, sesame, pistachios, molasses, soy beans, figs, quinoa, okra, rutabaga, broccoli, dandelion leaves, and kale. In addition, for some drinks like soymilk or orange juice, it is typical to be fortified with calcium. Numerous vegetables, notably spinach, chard, and rhubarb have high calcium content, but they may also contain varying amounts of oxalic acid that binds calcium and reduces its absorption. The same problem may to a degree affect the absorption of calcium from amaranth, collard and chicory greens. This process may also be related to the generation of calcium oxalate. An overlooked source of calcium is eggshell, which can be ground into a powder and mixed into food or a glass of water [22-24]. The calcium content of most foods can be found in the USDA National Nutrient Database [25].

Calcium supplements are used to prevent and to treat calcium deficiencies. Office of Dietary Supplements (National Institutes of Health) recommends that no more than $600 \mathrm{mg}$ of supplement should be taken at a time because the percent of calcium absorbed decreases as the amount of calcium in the supplement increases [26]. It is therefore recommended to spread doses throughout the day [27]. Recommended daily calcium intake for adult's ranges from 1000 to $1300 \mathrm{mg}$ [27]. Calcium supplements may have side effects such as bloating and constipation in some people. It is suggested that taking the supplements with food may aid in nullifying these side effects [27]. Vitamin D is added to some calcium supplements. Proper vitamin D status is important because vitamin D is converted to a hormone in the body, which then induces the synthesis of intestinal proteins responsible for calcium absorption [28].

A study investigating the effects of personal calcium supplement use on cardiovascular risk was reported in the Women's Health Initiative Calcium/Vitamin D Supplementation Study (WHI CaD Study) found a modestly increased risk of cardiovascular events, particularly myocardial infarction in postmenopausal women. A broad recommendation of calcium/ vitamin D supplements is therefore not warranted. In osteoporosis such studies often do not test calcium alone, but rather combinations of calcium and vitamin D. Randomized controlled clinical trials found both positive [29] and negative [30-33] effects. The different results may be explained by doses of calcium and underlying rates of calcium supplementation in the control groups [34]. A meta-analysis [35] by the international Cochrane Collaboration of two randomized controlled trials [36-37] found that calcium "might contribute to a moderate degree to the prevention of adenomatous colonic polyps. More recent studies were conflicting, and one that was positive for effect did control for a possible anti-carcinogenic effect of vitamin $\mathrm{D}$, which was found to be an independent positive influence from calcium-alone on cancer risk [38]. 
A randomized controlled trial found that $1000 \mathrm{mg}$ of elemental calcium and $400 \mathrm{IU}$ of vitamin $\mathrm{D}_{3}$ had no effect on colorectal cancer [39]. A randomized controlled trial found that 1400-1500 mg supplemental calcium and $1100 \mathrm{IU}$ vitamin $\mathrm{D}_{3}$ reduced aggregated cancers with a relative risk of 0.402 [40]. An observational cohort study found that high calcium and vitamin D intake was associated with lower risk of developing premenopausal breast cancer [41].

Compared with other metals, the calcium ion and most calcium compounds have low toxicity. This is not surprising given the very high natural abundance of calcium compounds in the environment and in organisms. Calcium poses few serious environmental problems, with kidney stones the most common side effect in clinical studies. Acute calcium poisoning is rare, and difficult to achieve unless calcium compounds are administered intravenously. For example, the oral median lethal dose $\left(\mathrm{LD}^{50}\right)$ for rats for calcium carbonate and calcium chloride are 6.45 [42] and $1.4 \mathrm{~g} / \mathrm{kg}$ [43] respectively.

Calcium metal is hazardous because of its sometimes-violent reactions with water and acids. Calcium metal is found in some drain cleaners where it functions to generate heat and calcium hydroxide that saponifies fats and liquefies proteins, e.g., hair that block drains. When swallowed calcium metal has the same effect on the mouth, esophagus and stomach, and can be fatal [44].

Excessive consumption of calcium carbonate antacids/dietary supplements, over a period of weeks or months can cause milk-alkali syndrome with symptoms ranging from hypercalcemia to potentially fatal renal failure. What constitutes "excessive" consumption is not well known and, it is presumed, varies a great deal from person to person. Persons consuming more than 10 grams/day of $\mathrm{CaCO}_{3}(=4 \mathrm{~g} \mathrm{Ca})$ are at risk of developing milk-alkali syndrome [45], but the condition has been reported in at least one person consuming only 2.5 grams/day of $\mathrm{CaCO}_{3}$ (=1 g Ca), an amount usually considered moderate and safe [46]. Oral calcium supplements diminish the absorption of thyroxine when taken within four to six hours of each other [47]. Thus, people taking both calcium and thyroxine run the risk of inadequate thyroid hormone replacement and thence hypothyroidism if they take them simultaneously or near-simultaneously [48]. Excessive calcium supplementation can be detrimental to cardiovascular health, especially in men $[49,50]$.

\subsection{Chromium}

Trivalent chromium ( $\mathrm{Cr}$ (III) or $\mathrm{Cr}^{3+}$ ) occurs in trace amounts in foods and waters, and appears to be benign [51]. In contrast, hexavalent chromium $\left(\mathrm{Cr}(\mathrm{VI})\right.$ or $\left.\mathrm{Cr}^{6+}\right)$ is very toxic and mutagenic when inhaled. $\mathrm{Cr}$ (VI) has not been established as a carcinogen when in solution, although it may cause allergic contact dermatitis (ACD) [52].

Chromium deficiency, involving a lack of Cr (III) in the body, or perhaps some complex of it, such as glucose tolerance factor is controversial, or is at least extremely rare. Chromium has no verified biological role and has been classified by some as not essential for mammals [53]. However, other reviews have regarded it as an essential trace element in humans [54]. It is a reddish crystalline powder, $12.5 \% \mathrm{Cr}$ (III) by weight, very sparingly soluble in water. Chromium deficiency has been attributed to only three people on long- 
term parenteral nutrition, which is when a patient is fed a liquid diet through intravenous drips for long periods of time [55].

Although no biological role for chromium has ever been demonstrated, dietary supplements for chromium include chromium (III), chromium (III) picolinate, chromium (III) polynicotinate, and related materials. The benefit of those supplements is questioned by some studies [56]. The use of chromium-containing dietary supplements is controversial, owing to the absence of any verified biological role, the expense of these supplements, and the complex effects of their use [57]. The popular dietary supplement chromium picolinate, complex generates chromosome damage in hamster cells (due to the picolinate ligand) [58]. In the United States the dietary guidelines for daily chromium uptake were lowered in 2001 from 50-200 $\mu \mathrm{g}$ for an adult to $35 \mu \mathrm{g}$ (adult male) and to $25 \mu \mathrm{g}$ (adult female)[59].

No comprehensive, reliable database of chromium content of food currently exists [60]. Data reported prior to 1980 is unreliable due to analytical error [56]. Chromium content of food varies widely due to differences in soil mineral content, growing season, plant cultivar, and contamination during processing. 60]. In addition, large amounts of chromium (and nickel) leech into food cooked in stainless steel [61,62].

The acute oral toxicity for chromium (VI) ranges between 50 and $150 \mu \mathrm{g} / \mathrm{kg}$ [61]. In the body, chromium (VI) is reduced by several mechanisms to chromium (III) already in the blood before it enters the cells. The chromium (III) is excreted from the body, whereas the chromate ion is transferred into the cell by a transport mechanism, by which also sulfate and phosphate ions enter the cell. The acute toxicity of chromium (VI) is due to its strong oxidational properties. After it reaches the blood stream, it damages the kidneys, the liver and blood cells through oxidation reactions. Hemolysis, renal and liver failure are the results of these damages. Aggressive dialysis can improve the situation [63].

The carcinogenity of chromate dust has been known for a long time. In 1890 the first publication described the elevated cancer risk of workers in a chromate dye company $[64,65]$. Three mechanisms have been proposed to describe the genotoxicity of chromium (VI). The first mechanism includes highly reactive hydroxyl radicals and other reactive radicals that are by products of the reduction of chromium (VI) to chromium (III). The second process includes the direct binding of chromium (V), produced by reduction in the cell, and chromium (IV) compounds to DNA. The last mechanism attributed the genotoxicity to the binding to the DNA of the end product of the chromium (III) reduction [66].

In some people chromium salts (chromates) are also the cause of allergic reactions. Chromates are often used to manufacture, amongst other things, leather products, paints, cement, mortar and anti-corrosives. Contact with products containing chromates can lead to allergic contact dermatitis and irritant dermatitis, resulting in ulceration of the skin, sometimes referred to as "chrome ulcers". This condition is often found in workers that have been exposed to strong chromate solutions in electroplating, tanning and chrome-producing manufacturers $[67,68]$. As chromium compounds were used in dyes and paints and leather tanning, these compounds are often found in soil and groundwater at abandoned industrial sites that now need envi- 
ronmental cleanup and remediation of contaminated land. Primer paint containing hexavalent chromium is still widely used for aerospace and automobile refinishing applications [69].

\subsection{Copper}

Copper is essential to all living organisms as a trace dietary mineral because it is a key constituent of the respiratory enzyme complex cytochrome c oxidase. In mollusks and crustacean copper is a constituent of the blood pigment hemocyanin, which is replaced by the iron-complexed hemoglobin in fish and other vertebrates. The main areas where copper is found in humans are liver, muscle and bone [70]. Copper compounds are used as bacteriostatic substances, fungicides and wood preservatives. Numerous antimicrobial efficacy studies have been conducted in the past 10 years regarding copper's efficacy to destroy a wide range of bacteria, as well as influenza A virus, adenovirus, and fungi [93].

Copper-alloy touch surfaces have natural intrinsic properties to destroy a wide range of microorganisms, E.coli, methicillin-resistant Staphylococcus aureus, influenza A virus, adenovirus, and fungi [71]. Some 355 copper alloys were proven to kill more than $99.9 \%$ of disease-causing bacteria within just two hours when cleaned regularly [72]. The U.S. Environmental Protection Agency (EPA) has approved the registrations of these copper alloys as antimicrobial materials with public health benefits [72], which allows manufacturers to legally make claims as to the positive public health benefits of products made with registered antimicrobial copper alloys. In addition, the EPA has approved a long list of antimicrobial copper products made from these alloys, such as bedrails, handrails, overbed tables, sinks, faucets, door knobs, toilet hardware, computer keyboards, health club equipment, shopping cart handles, etc. (for a comprehensive list of products. Copper doorknobs are used by hospitals to reduce the transfer of disease and Legionnaires' disease is suppressed by copper tubing in plumbing systems [73]. Antimicrobial copper alloy products are now being installed in healthcare facilities in the U.K., Ireland, Japan, Korea, France, Denmark, and Brazil and in the subway transit system in Santiago, Chile, where copper-zinc alloy handrails will be installed in some 30 stations by 2014 [74-76].

Copper proteins have diverse roles in biological electron transport and oxygen transportation, processes that exploit the easy interconversion of $\mathrm{Cu}$ (I) and $\mathrm{Cu}$ (II) [77-79]. The biological role for copper commenced with the appearance of oxygen in earth's atmosphere [80]. The protein hemocyanin is the oxygen carrier in most mollusks and some arthropods such as the horseshoe crab (Limulus polyphemus) [81]. Because hemocyanin is blue, these organisms have blue blood, not the red blood found in organisms that rely on hemoglobin for this purpose. Structurally related to hemocyanin are the lactases and tyrosinases. Instead of reversibly binding oxygen, these proteins hydroxylate substrates, illustrated by their role in the formation of lacquers [79].

Copper is also a component of other proteins associated with the processing of oxygen. In cytochrome coxidase, which is required for aerobic respiration, copper and iron cooperate in the reduction of oxygen. Copper is also found in many superoxide dismutases, proteins that catalyze the decomposition of superoxides, by converting it to oxygen and hydrogen peroxide: 


$$
2 \mathrm{HO}_{2} \longrightarrow \mathrm{H}_{2} \mathrm{O}_{2}+\mathrm{O}_{2}
$$

Several copper proteins, such as the "blue copper proteins" do not interact directly with substrates hence they are not enzymes. These proteins relay electrons by the process called electron transfer [79].

Copper is an essential trace element in plants and animals, but not in some microorganisms. The human body contains copper at a level of about 1.4 to $2.1 \mathrm{mg}$ per $\mathrm{kg}$ of body mass [82]. Stated differently, the recommended daily allowance (RDA) for copper in normal healthy adults is quoted in the range of $0.97 \mathrm{mg} /$ day to $3.0 \mathrm{mg} /$ day [83]. Copper is absorbed in the gut, and then transported to the liver then bound to albumin [84]. After processing in the liver, copper is distributed to other tissues in a second phase. Copper transport here involves the protein ceruloplasmin, which carries the majority of copper in blood. Ceruloplasmin also carries copper that is excreted in milk, and is particularly well absorbed as a copper source [85]. Copper in the body normally undergoes enterohepatic circulation (about $5 \mathrm{mg}$ a day, vs. about $1 \mathrm{mg}$ per day absorbed in the diet and excreted from the body), and the body is able to excrete some excess copper, if needed, via bile, which carries some copper out of the liver that is not then reabsorbed by the intestine [84,85].

Because of its role in facilitating iron uptake, copper deficiency can produce anemia-like symptoms, neutropenia, bone abnormalities, hypopigmentation, impaired growth, increased incidence of infections, osteoporosis, hyperthyroidism, and abnormalities in glucose and cholesterol metabolism. Conversely, Wilson's disease causes an accumulation of copper in body tissues. Severe deficiency can be found by testing for low plasma or serum copper levels, low ceruloplasmin, and low red blood cell superoxide dismutase levels; these are not sensitive to marginal copper status. The cytochrome c oxidase activity of leucocytes and platelets has been stated as another factor in deficiency, but the results have not been confirmed by replication [86].

Gram quantities of various copper salts have been taken in suicide attempts and produced acute copper toxicity in humans, possibly due to redox cycling and the generation of reactive oxygen species that damage DNA $[87,88]$. Corresponding amounts of copper salts $(30 \mathrm{mg} / \mathrm{kg})$ are toxic in animals [89]. A minimum dietary value for healthy growth in rabbits has been reported to be at least 3 ppm in the diet [90]. However, higher concentrations of copper (100 ppm, 200 ppm, or 500 ppm) in the diet of rabbits may favorably influence feed conversion ratio, growth rates, and carcass dressing percentages [91].

Chronic copper toxicity does not normally occur in humans because of transport systems that regulate absorption and excretion. Autosomal recessive mutations in copper transport proteins can disable these systems, leading to Wilson's disease with copper accumulation and cirrhosis of the liver in persons who have inherited two defective genes [82]. 


\subsection{Gold}

Gold is a chemical element with the symbol Au and atomic number 79. It is a dense, soft, malleable, and ductile metal with an attractive, bright yellow color and luster that is maintained without tarnishing in air or water. Chemically, gold is a transition metal and a group 11 element. It is one of the least reactive chemical elements, solid under standard conditions. The metal therefore occurs often in free elemental form, as nuggets or grains in rocks, in veins and in alluvial deposites. Less commonly, it occurs in minerals as gold compounds, such as with tellurium as calaverite, sylvanite and krennerite. Gold is perhaps the most anciently administered medicine [92] and known to the ancients [93-94] with apparent paradoxes with respect to its toxicology. This information suggests there are still serious gaps in understanding of action of gold on physiology [95].

In medieval times, gold was often seen as beneficial for the health, in the belief that something so rare and beautiful could not be anything but healthy. Even some modern esotericists and forms of alternative medicine assign metallic gold a healing power [96]. Some gold salts do have anti-inflammatory properties and are used as pharmaceuticals in the treatment of arthritis and other similar conditions. Gold-based injections have been explored as a means to help to reduce the pain and swelling of rheumatoid arthritis and tuberculosis [97]. However, only salts and radioisotopes of gold are of pharmacological value, as elemental (metallic) gold is inert to all chemicals it encounters inside the body.

Gold alloys are used in restorative dentistry, especially in tooth restorations, such as crowns and permanent bridges. The gold alloys' slight malleability facilitates the creation of a superior molar mating surface with other teeth and produces results that are generally more satisfactory than those produced by the creation of porcelain crowns. The use of gold crowns in more prominent teeth such as incisors is favored in some cultures and discouraged in others.

Colloidal gold preparations, such as the use of gold in nanoparticle suspensions in water are intensely red-colored, and can be made with tightly controlled particle sizes up to a few tens of nanometers across by reduction of gold chloride with citrate or ascorbate ions. Colloidal gold is used in research applications in medicine, biology and materials science. The technique of immunogold labeling exploits the ability of the gold particles to adsorb protein molecules onto their surfaces. Colloidal gold particles coated with specific antibodies can be used as probes for the presence and position of antigens on the surfaces of cells [98]. In ultrathin sections of tissues viewed by electron microscopy, the immunogold labels appear as extremely dense round spots at the position of the antigen [99].

Gold, or alloys of gold and palladium are applied as conductive coating to biological specimens and other non-conducting materials such as plastics and glass to be viewed in a scanning electron microscope. The coating, which is usually applied by sputtering with argon plasma, has a triple role in this application. Gold's very high electrical conductivity drains an electrical charge; therefore, its very high density provides stopping power for electrons in the electron beam, helping to limit the depth to which the electron beam penetrates the specimen. This improves definition of the position and topography of the specimen surface and increases the spatial resolution of the image. Gold also produces a high output of secondary electrons when 
irradiated by an electron beam, and these low-energy electrons are the most commonly used signal source in the scanning electron microscope [100]. The isotope gold-198 (half-life 2.7 days) is used in nuclear medicine, in some cancer treatments and for treating other diseases [101,102].

\subsection{Iodine}

Iodine and its compounds are primarily used in nutrition, and industrially in the production of acetic acid and certain polymers. Iodine's relatively high atomic number, low toxicity, and ease of attachment to organic compounds have made it a part of many X-ray contrast materials in modern medicine. Iodine has only one stable isotope. A number of iodine radioisotopes are also used in medical applications.

Iodine is found on Earth mainly as the highly water-soluble iodide ion 1-that concentrates it in oceans and brine pools. Like the other halogens, free iodine occurs mainly as a diatomic molecule $\mathrm{I}_{2}$, and then only momentarily after being oxidized from iodide by an oxidant like free oxygen. In the universe and on Earth, iodine's high atomic number makes it a relatively rare element. However, its presence in ocean water has given it a role in biology. It is the heaviest essential element utilized widely by life in biological functions. Iodine's rarity in many soils, due to initial low abundance as a crust-element, and also leaching of soluble iodide by rainwater, has led to many deficiency problems in land animals and inland human populations. Iodine deficiency affects about two billion people and is the leading preventable cause of intellectual disabilities [103].

Iodine is required by higher animals, which use it to synthesize thyroid hormones, which contain the element. Because of this function, radioisotopes of iodine are concentrated in the thyroid gland along with nonradioactive iodine. If inhaled, the radioisotope iodine-131, which has a high fission yield, concentrates in the thyroid, but is easily remedied with non-radioactive potassium iodide treatment.

Potassium iodide has been used as an expectorant, although this use is increasingly uncommon. In medicine, potassium iodide is usually used to treat acute thyrotoxicosis, usually as a saturated solution of potassium iodide. It is also used to block uptake of iodine-131 in the thyroid gland when this isotope is used as part of radiopharmaceuticals (such as iobenguane) that are not targeted to the thyroid or thyroid-type tissues.

Iodine-131, in the chemical form of iodide is a component of nuclear fallout and a particularly dangerous one owing to the thyroid gland's propensity to concentrate ingested iodine, where it is kept for periods longer than this isotope's radiological half-life of eight days. For this reason, if people are exposed to a significant amount of environmental radioactive iodine (iodine-131 in fallout), they may be instructed to take non-radioactive potassium iodide tablets. The typical adult dose is one $130 \mathrm{mg}$ tablet per 24 hours, supplying $100 \mathrm{mg}$ (100,000 micrograms) iodine, as iodide ion. Typical daily dose of iodine to maintain normal health is of order 100 micrograms. By ingesting this large amount of non-radioactive iodine, radioactive iodine uptake by the thyroid gland is minimized [104].

Diatrizoic acid, an iodine-containing radio contrast agent Iodine, as an element with high electron density and atomic number absorbs X-rays well. Therefore, it may be used as a radio 
contrast agent by filtering out imaging X-rays weaker than $33.3 \mathrm{keV}$, where iodine's innermost electrons begin absorbing X-rays strongly due to the photoelectric effect [105.] Organic compounds of a certain type (typically iodine-substituted benzene derivatives) are thus used in medicine as $X$-ray radio contrast agents for intravenous injection. This is often in conjunction with advanced X-ray techniques such as angiography and CT scanning. At present, all watersoluble radio contrast agents rely on iodine.

\subsection{Iron}

Iron is a chemical element with the symbol Fe (from Latin: ferrum) and atomic number 26. It is a metal in the first transition series. It is the most common element (by mass) forming the planet Earth as a whole, forming much of Earth's outer and inner core. It is the fourth most common element in the Earth's crust. Iron's very common presence is due to its abundant production as a result of fusion in high-mass stars, where the production of nickel-56 (which decays to the most common isotope of iron) is the last nuclear fusion reaction that is exothermic. This causes radioactive nickel to become the last element to be produced before collapse of a supernova leads to the explosive events that scatter this precursor radio nucleotide of iron abundantly into space.

Iron is abundant in biology [106]. Iron-proteins are found in all living organisms, ranging from the evolutionarily primitive archaea to humans. The color of blood is due to the hemoglobin, an iron-containing protein. As illustrated by hemoglobin, iron is often bound to cofactors, e.g. in hemes. The iron-sulfur clusters are pervasive and include nitrogenase, the enzymes responsible for biological nitrogen fixation. Influential theories of evolution have invoked a role for iron sulfides in the iron-sulfur world theory.

Structure of heme, in the protein additional ligand would be attached to Fe. Iron is a necessary trace element found in nearly all-living organisms. Iron-containing enzymes and proteins, often containing heme prosthetic groups participate in many biological oxidations and in transport. Examples of proteins found in higher organisms include hemoglobin, cytochrome and catalase [107]. Iron is pervasive, but particularly rich sources of dietary iron include red meat, lentils, beans, poultry, fish, leaf vegetables, watercress, tofu, chickpeas, black-eyed peas, blackstrap molasses, fortified bread, and fortified breakfast cereals. Iron in low amounts is found in molasses, teff and farina. Iron in meat (heme iron) is more easily absorbed than iron in vegetables [108]. Although some studies suggest that heme/hemoglobin from red meat has effects that may increase the likelihood of colorectal cancer $[109,110]$. There is still some controversy [111] and even a few studies suggesting that there is not enough evidence to support such claims [112].

Iron provided by dietary supplements is often found as iron (II) fumarate, although iron sulfate is cheaper and is absorbed equally well. Elemental iron, or reduced iron, despite being absorbed at only one third to two thirds the efficiency (relative to iron sulfate) [113] is often added to foods such as breakfast cereals or enriched wheat flour. Iron is most available to the body when chelated to amino acids [114] and is also available for use as a common iron supplement. Often the amino acid chosen for this purpose is the cheapest and most common amino acid, glycine, leading to "iron glycinate" supplements [115]. The Recommended Dietary 
Allowance (RDA) for iron varies considerably based on age, gender, and source of dietary iron (heme-based iron has higher bioavailability) [116]. Infants may require iron supplements if they are bottle-fed cow's milk [117]. Blood donors and pregnant women are at special risk of low iron levels and are often advised to supplement their iron intake [118]. Iron acquisition poses a problem for aerobic organisms, because ferric iron is poorly soluble near neutral $\mathrm{pH}$. Thus, bacteria have evolved high-affinity sequestering agents called siderophores [119-121].

After uptake, in cells, iron storage is carefully regulated as "free" as iron ions do not exist as free. A major component of this regulation is the protein transferrin, which binds iron ions absorbed from the duodenum and carries it in the blood to cells [122]. In animals, plants, and fungi, iron is often the metal ion incorporated into the heme complex. Heme is an essential component of cytochrome proteins, which mediate redox reactions, and of oxygen carrier proteins such as hemoglobin, myoglobin, and leg hemoglobin.

Inorganic iron contributes to redox reactions in the iron-sulfur clusters of many enzymes, such as nitrogenase involved in the synthesis of ammonia from nitrogen and hydrogen and hydrogenate. Non-heme iron proteins include the enzymes methane monooxygenase oxidizes methane to methanol, ribonucleotide reductase, reduces ribose to deoxyribose in DNA synthesis, hemerythrins involved in oxygen transport and fixation in marine invertebrates, and purple acid phosphatase hydrolysis of phosphate esters. Iron distribution is heavily regulated in mammals, partly because iron ions have a high potential for biological toxicity [123].

Iron uptake is tightly regulated by the human body, which has no regulated physiological means of excreting iron. Only small amounts of iron are lost daily due to mucosal and skin epithelial cell sloughing, so control of iron levels is mostly by regulating uptake [124]. Regulation of iron uptake is impaired in some people as a result of a genetic defect that maps to the HLA-H gene region on chromosome 6. In these people, excessive iron intake can result in iron overload disorders, such as hemochromatosis. Many people have a genetic susceptibility to iron overload without realizing it or being aware of a family history of the problem. For this reason, it is advised that people do not take iron supplements unless they suffer from iron deficiency and have consulted a doctor. Hemochromatosis is estimated to cause disease in between 0.3 and $0.8 \%$ of Caucasians [125]. MRI finds that iron accumulates in the hippocampus of the brains of those with Alzheimer's disease and in the substantia nigra of those with Parkinson disease [126].

Large amounts of ingested iron can cause excessive levels of iron in the blood. High blood levels of free ferrous iron react with peroxides to produce free radicals, which are highly reactive and can damage DNA, proteins, lipids, and other cellular components. Thus, iron toxicity occurs when there is free iron in the cell, which generally occurs when iron levels exceed the capacity of transferrin to bind the iron. Damage to the cells of the gastrointestinal tract can also prevent them from regulating iron absorption leading to further increases in blood levels. Iron typically damages cells in the heart, liver, and elsewhere, which can cause significant adverse effects, including coma, metabolic coma, metabolic acidosis, shock, liver failure, coagulopathy, adult respiratory distress syndrome, long-term organ damage, and even death [127]. Humans experience iron toxicity above 20 milligrams of iron for every kilogram 
of mass, and 60 milligrams per kilogram is considered a lethal dose [128]. Overconsumption of iron, often the result of children eating large quantities of ferrous sulfate tablets intended for adult consumption, is one of the most common toxicological causes of death in children under six [128]. The Dietary Reference Intake (DRI) lists the Tolerable Upper Intake Level (UL) for adults as $45 \mathrm{mg} /$ day. For children under fourteen years old the UL is $40 \mathrm{mg} /$ day. The medical management of iron toxicity is complicated and can include use of a specific chelating agent called deferoxamine to bind and expel excess iron from the body $[127,129]$.

\subsection{Lithium}

Lithium (from Greek lithos 'stone') is a chemical element with symbol Li and atomic number 3. It is a soft, silver-white metal belonging to the alkali metal group of chemical elements. Under standard conditions it is the lightest metal and the least dense solid element. Like all alkali metals, lithium is highly reactive and flammable. For this reason, it is typically stored in mineral oil. When cut open, lithium exhibits a metallic luster, but contact with moist air corrodes the surface quickly to a dull silvery gray, then black tarnish. Because of its high reactivity lithium never occurs freely in nature, and instead, only appears in compounds, which are usually ionic. Lithium occurs in a number of pegmatite minerals, but due to its solubility as an ion is present in ocean water and is commonly obtained from brines and clay. On a commercial scale, lithium is isolated electrolytically from a mixture of lithium chloride and potassium chloride. Lithium and its compounds have several industrial applications, including heat-resistant glass and ceramics, high strength-to-weight alloys used in aircraft, lithium batteries and lithium-ion batteries. These uses consume more than half of lithium production.

Trace amounts of lithium are present in all organisms. The element serves no apparent vital biological function, since animals and plants survive in good health without it; however, its central role in reproduction has been documented [130]. In the absence of lithium when tested in a number of vertebrate species (fowl, cows and goats) showed an increase in spontaneous abortions amongst these species. In humans lithium administered as any of several lithium salts has proved to be useful as a mood-stabilizing drug in the treatment of bipolar disorder due to neurological effects of the ion in the human body [131].

Lithium is found in trace amount in numerous plants, plankton, and invertebrates, at concentrations of 69 to 5,760 parts per billion (ppb). In vertebrates the concentration is slightly lower, and nearly all vertebrate tissue and body fluids have been found to contain lithium ranging from 21 to $763 \mathrm{ppb}$ [132]. Marine organisms tend to bioaccumulate lithium more than terrestrial ones [133]. It is not known whether lithium has a physiological role in any of these organisms [132], but nutritional studies in mammals have indicated its importance to health, leading to a suggestion that it be classed as an essential trace element with an RDA of $1 \mathrm{mg} /$ day [134]. Observational studies in Japan, reported in 2011, suggested that naturally occurring lithium in drinking water might increase human lifespan [135].

Lithium is useful in the treatment of bipolar disorder [136]. Lithium salts may also be helpful for related diagnoses, such as schizoaffective disorder and cyclic major depression. The active part of these salts is the lithium ion $\mathrm{Li}^{+}[137]$. They may increase the risk of developing Ebstein's cardiac anomaly in infants born to women who take lithium during the first trimester of 
pregnancy [135]. The most exciting results for lithium are its reported non-psychiatric medical effects that are centered on the ion's ability to influence the proliferation of stem cells first identified from hematopoietic tissues $[138,139]$. This effect has now been demonstrated to also take place in the regeneration of neurological tissues, thus the use of lithium to treat spinal chord injuries through a mechanism that involves enhancing stem cell regeneration of damaged neurons is very exciting.

\subsection{Magnesium}

Magnesium is a chemical element with the symbol $\mathrm{Mg}$ and atomic number 12. Its common oxidation number is +2 . It is an alkaline earth metal and the eighth most abundant element in the Earth's crust and ninth in the known universe as a whole [140]. Magnesium is the fourth most common element in the Earth as a whole (behind iron, oxygen and silicon), making up $13 \%$ of the planet's mass and a large fraction of the planet's mantle. The relative abundance of magnesium is related to the fact that it easily builds up in supernova stars from a sequential addition of three helium nuclei to carbon (which in turn is made from three helium nuclei). Due to magnesium ion's high solubility in water, it is the third most abundant element dissolved in seawater [141]. Magnesium is produced in stars larger than 3 solar masses by fusing helium and neon in the alpha process at temperatures above 600 megakelvins.

The free element (metal) is not found naturally on Earth, as it is highly reactive. Once produced, it is coated in a thin layer of oxide, which partly masks this reactivity. The free metal burns with a characteristic brilliant white light, making it a useful ingredient in flares. The metal is now mainly obtained by electrolysis of magnesium salts obtained from brine. Commercially, the chief use for the metal is as an alloying agent to make aluminum-magnesium alloys, sometimes called magnalium or magnelium. Since magnesium is less dense than aluminum these alloys are prized for their relative lightness and strength.

In human physiology, magnesium is the eleventh most abundant element by mass in the human body. Its ions are essential to all living cells, where they play a major role in manipulating important biological polyphosphate compounds like ATP, DNA, and RNA. Hundreds of enzymes thus require magnesium ions to function. Magnesium compounds are used medicinally as common laxatives, and antacids, e.g., milk of magnesia, and in a number of situations where stabilization of abnormal nerve excitation and blood vessel spasm is required (e.g., to treat eclampsia). Magnesium ions are sour to the taste, and in low concentrations they help to impart a natural tartness to fresh mineral waters.

Pharmaceutical preparations of magnesium are used to treat magnesium deficiency and hypomagnesemia, as well as eclampsia [142]. Usually in lower dosages, magnesium is commonly included in dietary mineral preparations, including many multivitamin preparations.

Sorted by type of magnesium salt, biological applications of magnesium include:

- Magnesium sulfate, as the heptahydrate called Epsom salts, is used as bath salts, as a laxative, and as a highly soluble fertilizer [143]. 
- Magnesium hydroxide, suspended in water, is used in milk of magnesia antacids and laxatives.

- Magnesium chloride, oxide, gluconate, malate, orotate, glycinate and citrate are all used as oral magnesium supplements. Some have claimed that oral magnesium supplements are therapeutic for Restless Leg Syndrome (RLS) in some individuals [144].

- Magnesium borate, magnesium salicylate, and magnesium sulfate are used as antiseptics.

- Magnesium bromide is used as a mild sedative (this action is due to the bromide, not the magnesium).

- Magnesium stearate is a slightly flammable white powder with lubricating properties. In pharmaceutical technology, it is used in the manufacturing of numerous kinds of tablets to prevent the tablets from sticking to the equipment during the tablet compression process (i.e., when the tablet's substance is pressed into tablet form).

Magnesium carbonate powder is used by athletes such as gymnasts, weightlifters and climbers to eliminate moisture and improves the grip on gymnastic apparatus, and lifting and climbing rocks.

Because of the important interaction between phosphate and magnesium ions, magnesium ions are essential to the basic nucleic acid chemistry of life, and thus are essential to all cells of all known living organisms. Over 300 enzymes require the presence of magnesium ions for their catalytic action, including all enzymes utilizing or synthesizing ATP, or those that use other nucleotides to synthesize DNA and RNA. ATP exists in cells normally as a chelate of ATP and a magnesium ion.

Plants have an additional use for magnesium in that chlorophylls are magnesium-centered porphyrins. Magnesium deficiency in plants causes late-season yellowing between leaf veins, especially in older leaves, and can be corrected by applying Epsom salts, which is rapidly leached, or else crushed dolomitic limestone to the soil.

Magnesium is a vital component of a healthy human diet. Human magnesium deficiency (including conditions that show few overt symptoms is relatively rare [145], although only $32 \%$ of people in the United States meet the RDA-DRI; [146] low levels of magnesium in the body has been associated with the development of a number of human illnesses such as asthma, diabetes, and osteoporosis [147]. Taken in the proper amount magnesium plays a role in preventing both stroke and heart attack. The symptoms of people with fibromyalgia, migraines, and girls going through their premenstrual syndrome are less severe and magnesium can shorten the length of the migraine symptoms [148,149].

Adult human bodies contain about 24 grams of magnesium, with 60\% in the skeleton, 39\% intracellular (20\% in skeletal muscle), and 1\% extracellular [150]. Serum levels are typically 0.7-1.0 mmol/L or 1.8-2.4 mEq/L. Serum magnesium levels may appear normal even in cases of underlying intracellular deficiency, although no known mechanism maintains a homeostatic level in the blood other than renal excretion of high blood levels. Intracellular magnesium is correlated with intracellular potassium. Magnesium is absorbed in the gastrointestinal tract, 
with more absorbed when status is lower. Magnesium competes with calcium in the human body [151]. In this way it actually keeps calcium in check. However, this can cause a calcium deficiency if calcium levels are already low [152]. Low and high protein intake inhibit magnesium absorption, and other factors such as phosphate, phytate, and fat affect absorption. Absorbed dietary magnesium is largely excreted through the urine, although most magnesium "administered orally" is excreted through the feces [153]. Magnesium status may be assessed roughly through serum and erythrocyte $\mathrm{Mg}$ concentrations and urinary and fecal excretion, but intravenous magnesium loading tests are likely the most accurate and practical in most people [154]. In these tests, magnesium is injected intravenously; retention of $20 \%$ or more indicates deficiency [155]. Other nutrient deficiencies are identified through biomarkers, but none are established for magnesium [156].

The UK recommended daily values for magnesium is $300 \mathrm{mg}$ for men and $270 \mathrm{mg}$ for women [157.] Spices, nuts, cereals, coffee, cocoa, tea, and vegetables are rich sources of magnesium [158]. Green leafy vegetables such as spinach are also rich in magnesium as they contain chlorophyll. Observations of reduced dietary magnesium intake in modern Western countries compared to earlier generations may be related to food refining and modern fertilizers that contain no magnesium [153].

Numerous pharmaceutical preparations of magnesium, as well as magnesium dietary supplements are available. Magnesium oxide, one of the most common forms in magnesium dietary supplements because it has high magnesium content per weight, has been reported the least bioavailable $[159,160]$. Magnesium citrate has been reported as more bioavailable than oxide or amino acid chelate forms [161].

Excess magnesium in the blood is freely filtered at the kidneys, and for this reason it is difficult to overdose on magnesium from dietary sources alone [148]. With supplements, overdose is possible, particularly in people with poor renal function; occasionally, with use of high cathartic doses of magnesium salts, severe hypermagnesemia has been reported to occur even without renal dysfunction [162]. Alcoholism can produce a magnesium deficiency, which is easily reversed by oral or parenteral administration, depending on the degree of deficiency [163]. Magnesium concentrations in plasma or serum may be measured to monitor for efficacy and safety in those receiving the drug therapeutically, to confirm the diagnosis in potential poisoning victims or to assist in the forensic investigation in a case of fatal over dosage. The newborn children of mothers who received parenteral magnesium sulfate during labor may exhibit toxicity at serum magnesium levels that were considered appropriate for the mothers [164].

There has been some speculation that magnesium deficiency can lead to depression. Cerebral spinal fluid (CSF) magnesium has been found low in treatment-resistant suicidal depression and in patients that have attempted suicide. Brain magnesium has been found low amounts using phosphorus nuclear magnetic resonance spectroscopy, an accurate means for measuring brain magnesium. Blood and cerebral spinal fluid (CSF) magnesium does not appear well correlated with major depression [165]. Magnesium chloride in relatively small doses was found as effective in the treatment of depressed elderly type 2 diabetics with hypomagnesemia as imipramine $50 \mathrm{mg}$ daily [166]. 
Results from a meta-analysis of randomized clinical trials demonstrated that magnesium supplementation lowers high blood pressure in a dose dependent manner [167]. Low serum magnesium levels are associated with metabolic syndrome, diabetes mellitus type 2 and hypertension [168]. Low serum magnesium levels have been associated with a higher risk of developing metabolic syndrome [169]. Magnesium therapy is recommended by the 2006 Guidelines for Management of Patients With Ventricular Arrhythmias and the Prevention of Sudden Cardiac Death for patients with ventricular arrhythmia associated with torsade de pointes that present with long QT syndrome as well as for the treatment of patients with digoxin intoxication-induced arrhythmias [170]. Magnesium is also the drug of choice in the management of pre-eclampsia and eclampsia [171].

Besides its therapeutic role, magnesium has an additional beneficial effect on calcification. Patients with chronic kidney disease have a high prevalence of vascular calcification, and cardiovascular disease is the leading cause of death in this population. Several in vitro and animal studies point towards a protective role of magnesium through multiple molecular mechanisms. Magnesium is a natural calcium antagonist and both human and animal studies have shown that low circulating magnesium levels are associated with vascular calcification [172]. Results from an observational study conducted in the general Japanese population demonstrated that lower serum magnesium levels were significantly and independently associated with a greater average intima-media thickness and the risk of at least two carotid plaques [173]. Magnesium supplementation might be useful in reducing the progression of atherosclerosis in chronic dialysis patients [174]. Low serum magnesium may be an independent risk factor for death in patients with chronic kidney disease [175] and patients with mildly elevated serum magnesium levels could have a survival advantage over those with lower magnesium levels [176].

Since the kidneys are responsible for the excretion of magnesium, anyone with a heart or kidney disorder should not take any extra magnesium except under their doctor's supervision. It is very rare to overdose on magnesium from food [152]; however people who ingest large amounts of milk of magnesia (as a laxative or antacid), Epsom Salts (as a laxative or tonic), or magnesium supplements may overdose, especially if they suffer from kidney problems. Too much magnesium can cause several serious health problems, including nausea, vomiting, severely lowered blood pressure, confusion, slowed heart rate, respiratory paralysis, deficiencies of other minerals, coma, cardiac arrhythmia, cardiac arrest, and death. At very high doses, it can even be fatal [152]. However the most common side effects of magnesium toxicity are stomach upset and diarrhea [36].

\subsection{Manganese}

Manganese is a chemical element designated by the symbol Mn. It has the atomic number 25. It is found as a free element in nature often in combination with iron and in many minerals. Manganese is a metal with important industrial metal alloy uses, particularly in stainless steels. In biology, manganese (II) ions function as cofactors for a large variety of enzymes with many functions [177]. Manganese enzymes are particularly essential in detoxification of superoxide free radicals in organisms that must deal with elemental oxygen. Manganese also functions in 
the oxygen-evolving complex of photosynthetic plants. The element is a required trace mineral for all known living organisms. In larger amounts, and apparently with far greater activity by inhalation, it can cause a poisoning syndrome in mammals, with neurological damage, which is sometimes irreversible.

Manganese is an essential trace nutrient in all known forms of life [178]. The classes of enzymes that have manganese cofactors are very broad, and include oxidoreductases, transferases, hydrolases, lyases, isomerases, ligases, lectins, and integrins. Reverse transcriptase found in many retroviruses contains manganese. The best-known manganese-containing polypeptides may be arginase, the diphtheria toxin and Mn-containing superoxide dismutase [179].

Mn-(super oxide dismutase (SOD) is the type of SOD present in eukaryotic mitochondria, and also in most bacteria (this fact is in keeping with the bacterial-origin theory of mitochondria). The Mn-SOD enzyme is probably one of the most ancient, for nearly all organisms living in the presence of oxygen use it to deal with the toxic effects of superoxide, formed from the 1electron reduction of oxygen. Exceptions include a few kinds of bacteria, and related lactobacilli, which use a different nonenzymatic mechanism, involving manganese $\left(\mathrm{Mn}^{2+}\right)$ ions complexed with polyphosphate directly for this task, indicating how this function possibly evolved in aerobic life.

The human body contains about $12 \mathrm{mg}$ of manganese, which is stored mainly in the bones; in the tissue, it is mostly concentrated in the liver and kidneys [20]. In the human brain, the manganese is bound to manganese metalloproteins, most notably glutamine synthetase in astrocytes [180]. Manganese is also important in photosynthetic oxygen evolution in chloroplasts in plants. The oxygen-evolving complex (OEC) is a part of photosystem II contained in the thylakoid membranes of chloroplasts; it is responsible for the terminal photo oxidation of water during the light reactions of photosynthesis, and has a metalloenzyme core containing four atoms of manganese [181]. For this reason, most broad-spectrum plant fertilizers contain manganese.

Manganese compounds are less toxic than those of other widespread metals, such as nickel and copper [182]. However, exposure to manganese dusts and fumes should not exceed the ceiling value of $5 \mathrm{mg} / \mathrm{m}^{3}$ even for short periods because of its toxicity level [183]. Manganese poisoning has been linked to impaired motor skills and cognitive disorders [184-186]. In 2005, a study suggested a possible link between manganese inhalation and central nervous system toxicity in rats [187]. The Occupational Safety and Health Administration in the United States regulates exposure to manganese [188]. Generally, exposure to ambient $\mathrm{Mn}$ air concentrations in excess of $5 \mu \mathrm{g} \mathrm{Mn} / \mathrm{m} 3$ can lead to Mn-induced symptoms. Increased ferroportin protein expression in human embryonic kidney (HEK293) cells is associated with decreased intracellular Mn concentration and attenuated cytotoxicity, characterized by the reversal of Mnreduced glutamate uptake and diminished lactate leakage [189].

Waterborne manganese has a greater bioavailability than dietary manganese. According to results from a 2010 study [190] higher levels of exposure to manganese in drinking water levels are associated with increased intellectual impairment and reduced intelligence quotients in school-age children. It is hypothesized that long-term exposure to the naturally occurring 
manganese in shower water puts up to 8.7 million Americans at risk [191-193]. Manganese overexposure is most frequently associated with manganism, a rare neurological disorder associated with excessive manganese ingestion or inhalation. Historically, persons employed in the production or processing of manganese alloys [194,195] have been at risk for developing manganism; however, current health and safety regulations protect workers in developed nations [158]. The disorder was first described in 1837 by British academic John Couper in two patients who were manganese grinders [196].

Manganism is a biphasic disorder. In its early stages, an intoxicated person may experience depression, mood swings, compulsive behaviors, and psychosis. Early neurological symptoms give way to late-stage manganism, which resembles Parkinson's disease. Symptoms include weakness, monotone and slowed speech, an expressionless face, tremor, forward-leaning gait, inability to walk backwards without falling, rigidity, and general problems with dexterity, gait and balance $[197,198]$. Unlike Parkinson's disease, manganism is not associated with loss of smell and patients are typically unresponsive to treatment with L-DOAP [195]. Symptoms of late-stage manganism become more severe over time even if the source of exposure is removed and brain manganese levels return to normal [197].

Several recent studies attempt to examine the effects of chronic low-dose manganese overexposure on development in children. The earliest study of this kind was conducted in the Chinese province of Shanxi. Drinking water there had been contaminated through improper sewage irrigation and contained 240-350 $\mathrm{mg} \mathrm{Mn} / \mathrm{L}$. Although WMn concentrations at or below $300 \mu \mathrm{g} \mathrm{Mn} / \mathrm{L}$ are considered safe by the US EPA and $400 \mu \mathrm{g} \mathrm{Mn} / \mathrm{L}$ are considered safe by the World Health Organization, the 92 children sampled (between 11 and 13 years of age) from this province displayed lower performance on tests of manual dexterity and rapidity, shortterm memory, and visual identification when compared to children from an uncontaminated area. More recently, a study of 10-year-old children in Bangladesh showed a relationship between WMn concentration in well water and diminished IQ scores. A third study conducted in Quebec examined school children between the ages of 6 and 15 living in homes that received water from a well containing $610 \mu \mathrm{g} \mathrm{Mn} / \mathrm{L}$; controls lived in homes that received water from a $160 \mu \mathrm{g} \mathrm{Mn/L} \mathrm{well.} \mathrm{Children} \mathrm{in} \mathrm{the} \mathrm{experimental} \mathrm{group} \mathrm{showed} \mathrm{increased} \mathrm{hyperactive} \mathrm{and}$ oppositional behaviors [192].

Chronic low-dose manganese intoxication is strongly implicated in a number of neurodegenerative disorders, including Alzheimer's disease, Parkinson's disease, and amyotrophic lateral sclerosis. It may also play a role in the development of multiple sclerosis, restless leg syndrome, and Huntington's disease. A protein called DMT1 is the major transporter involved in manganese absorption from the intestine, and may be the major transporter of manganese across the blood-brain barrier. DMT1 also transports inhaled manganese across the nasal epithelium. The putative mechanism of action is that manganese overexposure and/or dysregulation lead to oxidative stress, mitochondrial dysfunction, glutamate-mediated excitoxicity, and aggregation of proteins. 


\subsection{Platinum}

Platinum is a chemical element with the chemical symbol Pt and an atomic number of 78 . Its name is derived from the Spanish term platina, which is literally translated into "little silver" [198,199]. It is a dense, malleable, ductile, precious, gray-white transition metal. Platinum is used in catalytic converters, laboratory equipment, electrical contacts and electrodes, platinum resistance thermometers, dentistry equipment, and jewelry. Because only a few hundred tons are produced annually, it is a scarce material, and is highly valuable and is a major precious metal commodity. Being a heavy metal, it leads to health issues upon exposure to its salts, but due to its corrosion resistance, it is not as toxic as some metals [200]. Compounds containing platinum, most notably cisplatin, are applied in chemotherapy against certain types of cancer [201].

In the laboratory, platinum wire is used for electrodes; platinum pans and supports are used in thermo gravimetric analysis because of the stringent requirements of chemical inertness upon heating to high temperatures $\left(\sim 1000^{\circ} \mathrm{C}\right)$. Platinum is used as an alloying agent for various metal products, including fine wires, noncorrosive laboratory containers, medical instruments, dental prostheses, electrical contacts, and thermocouples. Platinum-cobalt, an alloy of roughly three parts platinum and one part cobalt, is used to make relatively strong permanent magnets $[202,203]$. Platinum-based anodes are used in ships, pipelines, and steel piers [204]. According to the Centers for Disease Control and Prevention, short-term exposure to platinum salts may cause irritation of the eyes, nose, and throat, and long-term exposure may cause both respiratory and skin allergies. The current OSHA standard is 2 micrograms per cubic meter of air averaged over an 8-hour work shift [205].

Platinum-based antineoplastic agents are used in chemotherapy, and show good activity against some tumors. As platinum is a catalyst in the manufacture of the silicone rubber and gel components of several types of medical implants (breast implants, joint replacement prosthetics, artificial lumbar discs, vascular access ports, etc.), the possibility platinum could enter the body and cause adverse effects have merited study. The Food and Drug Administration and other institutions have reviewed the issue and found no evidence to suggest toxicity in vivo [206,207].

\subsection{Potassium}

Potassium is a chemical element with symbol K (from Neo-Latin kalium) and atomic number 19. Elemental potassium is a soft silvery-white alkali metal that oxidizes rapidly in air and is very reactive with water, generating sufficient heat to ignite the hydrogen emitted in the reaction and burning with a lilac flame.

Potassium ions are necessary for the function of all living cells. Potassium ion diffusion is a key mechanism in nerve transmission, and potassium depletion in animals, including humans, results in various cardiac dysfunctions. Potassium accumulates in plant cells, and thus fresh fruits and vegetables are a good dietary source of it. Conversely, most plants except specialist halophytes are intolerant of salt, and sodium is present in them only in low concentrations. This resulted in potassium first being isolated from potash, the ashes 
of plants, giving the element its name. For the same reason, heavy crop production rapidly depletes soils of potassium, and agricultural fertilizers consume $95 \%$ of global potassium chemical production [208].

Potassium is the eighth or ninth most common element by mass $(0.2 \%)$ in the human body, so that a $60 \mathrm{~kg}$ adult contains a total of about $120 \mathrm{~g}$ of potassium [209]. The body has about as much potassium as sulfur and chlorine, and only the major minerals calcium and phosphorus are more abundant [210].

Potassium cations are important in neuron (brain and nerve) function, and in influencing osmotic balance between cells and the interstitial fluid, with their distribution mediated in all animals (but not in all plants) by the so-called $\mathrm{Na}+/ \mathrm{K}+\mathrm{ATPase}$ pump [211]. This ion pump uses ATP to pump three sodium ions out of the cell and two potassium ions into the cell, thus creating an electrochemical gradient over the cell membrane. In addition, the highly selective potassium ion channels (which are tetramers) are crucial for the hyperpolarization, in for example neurons, after an action potential is fired. The most recently resolved potassium ion channel is KirBac3.1, which gives a total of five potassium ion channels (KcsA, KirBac1.1, KirBac3.1, KvAP, and MthK) with a determined structure [212]. All five are from prokaryotic species.

Potassium can be detected by taste because it triggers three of the five types of taste sensations, according to concentration. Dilute solutions of potassium ions taste sweet, allowing moderate concentrations in milk and juices, while higher concentrations become increasingly bitter/ alkaline, and finally also salty to the taste. The combined bitterness and saltiness of highpotassium solutions makes high-dose potassium supplementation by liquid drinks a palatability challenge $[213,214]$. Potassium is also important in preventing muscle contraction and the sending of all nerve impulses in animals through action potentials. By nature of their electrostatic and chemical properties, $\mathrm{K}^{+}$ions are larger than $\mathrm{Na}^{+}$ions, and ion channels and pumps in cell membranes can distinguish between the two types of ions, actively pumping or passively allowing one of the two ions to pass, while blocking the other [215]. A shortage of potassium in body fluids may cause a potentially fatal condition known as hypokalemia, typically resulting from vomiting, diarrhea, and/or increased diuresis [216]. Deficiency symptoms include muscle weakness, paralytic ileus, ECG abnormalities, decreased reflex response and in severe cases respiratory paralysis, alkalosis and cardiac arrhythmia [217].

Potassium is an essential macro mineral in human nutrition; it is the major cation (positive ion) inside animal cells, and it is thus important in maintaining fluid and electrolyte balance in the body. Sodium makes up most of the cations of blood plasma at a reference range of about 145 $\mathrm{mmol} / \mathrm{L}(3.345 \mathrm{~g})(1 \mathrm{mmol} / \mathrm{L}=1 \mathrm{mEq} / \mathrm{L})$, and potassium makes up most of the cell fluid cations at about $150 \mathrm{mmol} / \mathrm{L}(4.8 \mathrm{~g})$. Plasma is filtered through the glomerulus of the kidneys in enormous amounts, about 180 liters per day [218]. Thus $602 \mathrm{~g}$ of sodium and $33 \mathrm{~g}$ of potassium are filtered each day. All but the 1-10 g of sodium and the 1-4 g of potassium likely to be in the diet must be reabsorbed. Sodium must be reabsorbed in such a way as to keep the blood volume exactly right and the osmotic pressure correct; potassium must be reabsorbed in such a way as to keep serum concentration as close as possible to $4.8 \mathrm{mmol} / \mathrm{L}$ (about $0.190 \mathrm{~g} / \mathrm{L}$ ) [219]. Sodium pumps in the kidneys must always operate to conserve sodium. Potassium must 
sometimes be conserved also, but, as the amount of potassium in the blood plasma is very small and the pool of potassium in the cells is about thirty times as large, the situation is not so critical for potassium. Since potassium is moved passively $[220,221]$ in counter flow to sodium in response to an apparent (but not actual) Donnan equilibrium [222] the urine can never sink below the concentration of potassium in serum except sometimes by actively excreting water at the end of the processing. Potassium is secreted twice and reabsorbed three times before the urine reaches the collecting tubules [223]. At that point, it usually has about the same potassium concentration as plasma. At the end of the processing, potassium is secreted one more time if the serum levels are too high. If potassium were removed from the diet, there would remain a minimum obligatory kidney excretion of about $200 \mathrm{mg}$ per day when the serum declines to $3.0-3.5 \mathrm{mmol} / \mathrm{L}$ in about one week [224] and can never be cut off completely, resulting in hypokalemia and even death [225].

The potassium moves passively through pores in the cell membrane. When ions move through pumps there is a gate in the pumps on either side of the cell membrane and only one gate can be open at once. As a result, approximately 100 ions are forced through per second. Pores have only one gate, and there is only one kind of ion that can stream through, at 10 million to 100 million ions per second [226]. The pores require calcium in order to open [225] although it is thought that the calcium works in reverse by blocking at least one of the pores [228]. Carbonyl groups inside the pore on the amino acids mimic the water hydration that takes place in water solution [229] by the nature of the electrostatic charges on four carbonyl groups inside the pore [230].

A potassium intake sufficient to support life can in general be guaranteed by eating a variety of foods. Clear cases of potassium deficiency (as defined by symptoms, signs and a belownormal blood level of the element) are rare in healthy individuals. Foods rich in potassium include parsley, dried apricots, dried milk, chocolate, various nuts (especially almonds and pistachios), potatoes, bamboo shoots, bananas, avocados, soybeans, and bran, although it is also present in sufficient quantities in most fruits, vegetables, meat and fish [231].

Epidemiological studies and studies in animals subject to hypertension indicate that diets high in potassium can reduce the risk of hypertension and possibly stroke (by a mechanism independent of blood pressure), and a potassium deficiency combined with an inadequate thiamine intake has produced heart disease in rats [232]. There is some debate regarding the optimal amount of dietary potassium. For example, the 2004 guidelines of the Institute of Medicine specify a DRI of 4,700 mg of potassium (100 mEq), though most Americans consume only half that amount per day, which would make them formally deficient as regards this particular recommendation [233, 234]. Likewise, in the European Union, in particular in Germany and Italy, insufficient potassium intake is somewhat common [235]. Italian researchers reported in a 2011 meta-analysis that a $1.64 \mathrm{~g}$ higher daily intake of potassium was associated with a $21 \%$ lower risk of stroke [234].

Supplements of potassium in medicine are most widely used in conjunction with loop diuretics and thiazides, classes of diuretics that rid the body of sodium and water, but have the side effect of also causing potassium loss in urine. A variety of medical and non-medical supplements are available. Potassium salts such as potassium chloride may be dissolved in water, 
but the salty/bitter taste of high concentrations of potassium ion make palatable high concentration liquid supplements difficult to formulate [234]. Typical medical supplemental doses range from $10 \mathrm{mmol}$ (400 mg, about equal to a cup of milk or 6 US flu oz (180 ml) of orange juice) to $20 \mathrm{mmol}(800 \mathrm{mg}$ ) per dose. Potassium salts are also available in tablets or capsules, which for therapeutic purposes are formulated to allow potassium to leach slowly out of a matrix, as very high concentrations of potassium ion (which might occur next to a solid tablet of potassium chloride) can kill tissue, and cause injury to the gastric or intestinal mucosa. For this reason, law in the US to only $99 \mathrm{mg}$ of potassium limits non-prescription supplement potassium pills.

Individuals suffering from kidney diseases may experience adverse health effects from consuming large quantities of dietary potassium. End stage renal failure patients undergoing therapy by renal dialysis must observe strict dietary limits on potassium intake, as the kidneys control potassium excretion, and buildup of blood concentrations of potassium (hyperkalemia) may trigger fatal cardiac arrhythmia.

\subsection{Selenium}

Selenium is a chemical element with symbol Se and atomic number 34. It is a nonmetal with properties that are intermediate between those of its periodic table column-adjacent chalcogen elements sulfur and tellurium. It rarely occurs in its elemental state in nature, or as pure ore compounds. Jons Jacob Berselius, who noted the similarity of the new element to the previously known tellurium, discovered selenium in 1817.

Selenium salts are toxic in large amounts, but trace amounts are necessary for cellular function in many organisms, including all animals. Selenium is a component of the antioxidant enzymes glutathione peroxidase and thioredoxin reductase (which indirectly reduce certain oxidized molecules in animals and some plants). It is also found in three deiodinase enzymes, which convert one thyroid hormone to another. Selenium requirements in plants differ by species, with some plants requiring relatively large amounts, and others apparently requiring none [237].

Although it is toxic in large doses, selenium is an essential micronutrient for animals. In plants, it occurs as a bystander mineral, sometimes in toxic proportions in forage (some plants may accumulate selenium as a defense against being eaten by animals, but other plants such as locoweed require selenium, and their growth indicates the presence of selenium in soil) [237]. Selenium is a component of the unusual amino acids selenocysteine and selenomethionine. In humans, selenium is a trace element nutrient that functions as cofactor for reduction of antioxidant enzymes, such as glutathione peroxidases [238] and certain forms of thioredoxin reductase found in animals and some plants (this enzyme occurs in all living organisms, but not all forms of it in plants require selenium).

The glutathione peroxidase family of enzymes (GSH-Px) catalyzes certain reactions that remove reactive oxygen species such as hydrogen peroxide and organic hydroperoxides. 


$$
2 \mathrm{GSH}+\mathrm{H}_{2} \mathrm{O}_{2}----\mathrm{GSH}-\mathrm{Px} \longrightarrow \mathrm{GSSG}+2 \mathrm{H}_{2} \mathrm{O}
$$

Selenium also plays a role in the functioning of the thyroid gland and in every cell that uses thyroid hormone, by participating as a cofactor for the three of the four known types of thyroid hormone deiodinases, which activate and then deactivate various thyroid hormones and their metabolites: the iodothyronine deiodinases are the subfamily of deiodinase enzymes that use selenium as the otherwise rare amino acid selenocysteine. Only the deiodinase iodotyrosine, which works on the last breakdown products of thyroid hormone, does not use selenium [239].

Selenium may inhibit Hashimoto's disease, in which the bodies own thyroid cells are attacked as alien. A reduction of $21 \%$ in antibodies was reported with the dietary intake of $0.2 \mathrm{mg}$ of selenium [240]. Increased dietary selenium intakes reduce the effects of mercury toxicity [241] and it is now recognized that the molecular mechanism of mercury toxicity involves irreversible inhibition of selenoenzymes that are required to prevent and reverse oxidative damage in brain and endocrine tissues [242,243]. Dietary selenium comes from nuts, cereals, meat, mushrooms, fish, and eggs. Brazil nuts are the richest ordinary dietary source (though this is soil-dependent, since the Brazil nut does not require high levels of the element for its own needs). In descending order of concentration, high levels are also found in kidney, tuna, crab, and lobster [244,245].

The human body's content of selenium is believed to be in the 13-20 milligram range [246]. The substance loosely called selenium sulfide (approximate formula $\mathrm{SeS}_{2}$ ) is the active ingredient in some anti-dandruff shampoos [247]. The selenium compound kills the scalp fungus Malassezia, which causes shedding of dry skin fragments. The ingredient is also used in body lotions to treat Tinea versicolor due to infection by a different species of Malassezia fungus [248].

Selenium may be measured in blood, plasma, serum or urine to monitor excessive environmental or occupational exposure, confirm a diagnosis of poisoning in hospitalized victims or to assist in a forensic investigation in a case of fatal over dosage. Some analytical techniques are capable of distinguishing organic from inorganic forms of the element. Both organic and inorganic forms of selenium are largely converted to monosaccharide conjugates (selenosugars) in the body prior to being eliminated in the urine. Cancer patients receiving daily oral doses of selenothionine may achieve very high plasma and urine selenium concentrations [249]. Selenium deficiency is rare in healthy, well-nourished individuals. It can occur in patients with severely compromised intestinal function, those undergoing total parenteral nutrition, and [250] in those of advanced age (over 90). Also, people dependent on food grown from selenium-deficient soil are at risk. Although New Zealand has low levels of selenium in its soil, adverse health effects have not been detected [251]. Selenium deficiency as defined by low ( $<60 \%$ of normal) selenoenzyme activity levels in brain and endocrine tissues only occurs when a low selenium status is linked with an additional stress, such as high exposures to mercury [252] or as a result of increased oxidant stress due to vitamin E deficiency [253].

There are interactions between selenium and other nutrients, such as iodine and vitamin E. The effect of selenium deficiency on health remains uncertain, particularly in relation to 
Kashin-Beck disease [254]. Also, there are interactions between selenium and other minerals, such as zinc and copper, it seems that high does of Se supplement to pregnant animal might disturb the $\mathrm{Zn}: \mathrm{Cu}$ ratio which, in turn, leads to $\mathrm{Zn}$ reduction. It can be concluded that the $\mathrm{Zn}$ status should be monitored when high dose of $S e$ is supplemented to pregnant animal. Further studies needs to be done with higher levels of Se supplement to confirm these interactions [255].

In some regions (e.g. various regions within North America) where low available selenium levels in soil lead to low concentrations in dry matter of plants, Se deficiency in some animal species may occur unless dietary (or injected) selenium supplementation is done [256]. Ruminants are particularly susceptible. In general, absorption of dietary selenium is lower in ruminants than in non-ruminants, and is lower from forages than from grain [257] Ruminants grazing certain forages, e.g. some white clover varieties containing cyanogenic glycosides, may have higher selenium requirements, [258] presumably because of cyanide from the aglycone released by glucosidase activity in the rumen [258] and inactivation of glutathione peroxidases due to absorbed cyanide's effect on the glutathione moiety [260]. Neonate ruminants at risk of WMD (white muscle disease) may be administered both selenium and vitamin $\mathrm{E}$ by injection; some of the WMD myopathies respond only to selenium, some only to vitamin E, and some to either [261]. A number of correlative epidemiological studies have implicated selenium deficiency (as measured by blood levels) in a number of serious or chronic diseases, such as cancer [259], diabetes [262], HIV/ AIDS [263] and tuberculosis. In addition, selenium supplementation has been found to be a chemopreventive for some types of cancer in some types of rodents. However, in randomized, blinded, controlled prospective trials in humans, selenium supplementation has not succeeded in reducing the incidence of any disease, nor has a meta-analysis of such selenium supplementation studies detected a decrease in overall mortality [264].

\subsection{Sodium}

Sodium is a chemical element with the symbol $\mathrm{Na}$ (from Latin: natrium) and atomic number 11. It is a soft, silvery-white, highly reactive metal and is a member of the alkali metals; its only stable isotope is ${ }^{23} \mathrm{Na}$. The free metal does not occur in nature, but instead must be prepared from its compounds; was first isolated by Humphry Davy in 1807 by the electrolysis of sodium hydroxide. Sodium is the sixth most abundant element in the Earth's crust, and exists in numerous minerals such as feldspars and rock salt. Many salts of sodium are highly watersoluble, and their sodium has been leached by the action of water so that chloride and sodium $(\mathrm{NaCl})$ are the most common dissolved elements by weight in the Earth's bodies of oceanic water.

In humans, sodium is an essential nutrient that regulates blood volume, blood pressure, osmotic equilibrium and $\mathrm{pH}$; the minimum physiological requirement for sodium is 500 milligrams per day [265]. Sodium chloride is the principal source of sodium in the diet, and is used as seasoning and preservative, such as for pickling and jerky; most of it comes from processed foods [266]. The DRI for sodium is 2.3 grams per day [266], but on average people in the United States consume 3.4 grams per day [267], the minimum amount that promotes hypertension [268]; this in turn causes 7.6 million premature deaths worldwide [269]. 
The renin-angiotensin system regulates the amount of fluids and sodium in the body. Reduction of blood pressure and sodium concentration in the kidney results in the production of renin, which in turn produces aldosterone and angiotensin, retaining sodium in the urine. Because of the increase in sodium concentration, the production of renin decreases, and the sodium concentration returns to normal [270]. Sodium is also important in neuron function and osmoregulation between cells and the extracellular fluid, their distribution mediated in all animals by $\mathrm{Na}+/ \mathrm{K}+-\mathrm{ATPase}$ [271]; hence, sodium is the most prominent cation in extracellular fluid [272].

In C4 plants, sodium is a micronutrient that aids in metabolism, specifically in regeneration of phosphoenolpyruvate and synthesis of chlorophyll [273]. In others, it substitutes for potassium in several roles, such as maintaining turgor pressure and aiding in the opening and closing of stomata [274]. Excess sodium in the soil limits the uptake of water due to decreased water potential, which may result in wilting; similar concentrations in the cytoplasm can lead to enzyme inhibition, which in turn causes necrosis and chlorosis [275]. To avoid these problems, plants developed mechanisms that limit sodium uptake by roots, store them in cell vacuoles, and control them over long distances [276]; excess sodium may also be stored in old plant tissue, limiting the damage to new growth.

\subsection{Zinc}

Zinc, in commerce also spelter, is a metallic chemical element; it has the symbol $\mathrm{Zn}$ and atomic number 30. It is the first element of group 12 of the periodic table. Zinc is, in some respects, chemically similar to magnesium, because its ion is of similar size and its only common oxidation state is +2 . Zinc is the 24th most abundant element in the Earth's crust and has five stable isotopes. The most common zinc ore is sphalerite (zinc blende), a zinc sulfide mineral. The largest mineable amounts are found in Australia, Asia, and the United States. Zinc production includes froth flotation of the ore, roasting, and final extraction using electricity.

Zinc is an essential mineral of "exceptional biologic and public health importance" [277]. Zinc deficiency affects about two billion people in the developing world and is associated with many diseases [278]. In children it causes growth retardation, delayed sexual maturation, infection susceptibility, and diarrhea, contributing to the death of about 800,000 children worldwide per year [277]. Enzymes with a zinc atom in the reactive center are widespread in biochemistry, such as alcohol dehydrogenase in humans [279]. Consumption of excess zinc can cause ataxia, lethargy and copper deficiency.

Zinc is included in most single tablet over-the-counter daily vitamin and mineral supplements [280]. Preparations include zinc oxide, zinc acetate, and zinc gluconate [281]. It is believed to possess antioxidant properties, which may protect against accelerated aging of the skin and muscles of the body; studies differ as to its effectiveness [282]. Zinc also helps speed up the healing process after an injury [281]. It is also suspected of being beneficial to the body's immune system. Indeed, zinc deficiency may have effects on virtually all parts of the human immune system [282]. The efficacy of zinc compounds when used to reduce the duration or severity of cold symptoms is controversial [283]. A 2011 systemic review concludes that supplementation yields a mild decrease in duration and severity of cold symptoms [284]. 
Optimum dosing and formulation have not been determined. The studies included in the 2011 review used a variety of forms and doses of zinc, including zinc gluconate or zinc acetate lozenges and zinc sulfate syrup. The doses ranged from 30 to 160 milligrams per day. The researchers noted the following: "Given the variability in the populations studied (no studies from low-or middle-income countries), dose, formulation and duration of zinc used in the included studies, more research is needed to address these variabilities and determine the optimal duration of treatment as well as the dosage and formulations of zinc that will produce clinical benefits without increasing adverse effects, before making a general recommendation for zinc in treatment of the common cold."

Zinc serves as a simple, inexpensive, and critical tool for treating diarrheal episodes among children in the developing world. Zinc becomes depleted in the body during diarrhea, but recent studies suggest that replenishing zinc with a 10-to 14-day course of treatment can reduce the duration and severity of diarrheal episodes and may also prevent future episodes for up to three months [285]. The Age-Related Eye Disease Study determined that zinc could be part of an effective treatment for age-related macular degeneration [286]. Zinc supplementation is an effective treatment for acrodermatitis enteropathica, a genetic disorder affecting zinc absorption that was previously fatal to babies born with it [287]. Gastroenteritis is strongly attenuated by ingestion of zinc, and this effect could be due to direct antimicrobial action of the zinc ions in the gastrointestinal tract, or to the absorption of the zinc and re-release from immune cells (all granulocytes secrete zinc), or both [288,289]. In 2011, researchers at John Jay College of Criminal Justice reported that dietary zinc supplements could mask the presence of drugs in urine. Similar claims have been made in web forums on that topic [289].

Although not yet tested as a therapy in humans, a growing body of evidence indicates that zinc may preferentially kill prostate cancer cells. Because zinc naturally homes to the prostate and because the prostate is accessible with relatively non-invasive procedures, its potential as a chemotherapeutic agent in this type of cancer has shown promise [290]. However, other studies have demonstrated that chronic use of zinc supplements in excess of the recommended dosage may actually increase the chance of developing prostate cancer, also likely due to the natural buildup of this heavy metal in the prostate [291]. Topical zinc preparations include those used on the skin, often in the form of zinc oxide. Zinc preparations can protect against sunburn in the summer and windburn in the winter [292]. Applied thinly to a baby's diaper area (perineum) with each diaper change, it can protect against diaper rash [292]. Zinc lactate is used in toothpaste to prevent halitosis [138]. Zinc pyrithione is widely applied in shampoos because of its anti-dandruff function [293]. Zinc ions are effective antimicrobial agents even at low concentrations [294].

Zinc is an essential trace element, necessary for plants [295], animals [296], and microorganisms [297]. Zinc is found in nearly 100 specific enzymes [298], serves as structural ions in transcription factors and is stored and transferred in metallothioneins [299]. It is "typically the second most abundant transition metal in organisms" after iron and it is the only metal that appears in all enzyme classes [295]. In proteins, $\mathrm{Zn}$ ions are often coordinated to the amino acid side chains of aspartic acid, glutamic acid, cysteine and histidine. The theoretical and computational description of this zinc binding in proteins (as well as that of other transition metals) is difficult [300]. There are 2-4 grams of zinc [301] distributed throughout the human body. Most zinc is 
in the brain, muscle, bones, kidney, and liver, with the highest concentrations in the prostate and parts of the eye [302]. Semen is particularly rich in zinc, which is a key factor in prostate gland function and reproductive organ growth [303].

In humans, zinc plays "ubiquitous biological roles"[275.] It interacts with a wide range of organic ligands [275], and has roles in the metabolism of RNA and DNA, signal transduction, and gene expression. It also regulates apoptosis. A 2006 study estimated that about $10 \%$ of human proteins (2800) potentially bind zinc, in addition to hundreds which transport and traffic zinc; a similar in silico study in the plant Arabidopsis thaliana found 2367 zinc-related proteins [293].

In the brain, zinc is stored in specific synaptic vesicles by glutamatergic neurons [304] and can modulate brain excitability [305]. It plays a key role in synaptic plasticity and so in learning [159]. However, it has been called the brain's dark horse [306] since it also can be a neurotoxin, suggesting zinc homeostasis plays a critical role in normal functioning of the brain and central nervous system [307]. Zinc deficiency is usually due to insufficient dietary intake, but can be associated with malabsorption, acrodermatitis enteropathica, chronic liver disease, chronic renal disease, sickle cell disease, diabetes, malignancy, and other chronic illnesses [4]. Symptoms of mild zinc deficiency are diverse [308]. Clinical outcomes include depressed growth, diarrhea, impotence and delayed sexual maturation, alopecia, eye and skin lesions, impaired appetite, altered cognition, impaired host defense properties, defects in carbohydrate utilization, and reproductive teratogenesis [305]. Mild zinc deficiency depresses immunity [306], although excessive zinc does also [299]. Animals with a diet deficient in zinc require twice as much food in order to attain the same weight gain as animals given sufficient zinc [309]. Groups at risk for zinc deficiency include the elderly, children in developing countries, and those with renal insufficiency. The zinc chelator phytate, found in seeds and cereal bran, can contribute to zinc malabsorption [278].

Despite some concerns [310], western vegetarians and vegans have not been found to suffer from overt zinc deficiencies any more than meat-eaters [311]. Major plant sources of zinc include cooked dried beans, sea vegetables, fortified cereals, soy foods, nuts, peas, and seeds [306]. However, phytates in many whole-grains and fiber in many foods may interfere with zinc absorption and marginal zinc intake has poorly understood effects. There is some evidence to suggest that more than the US RDA ( $15 \mathrm{mg}$ ) of zinc daily may be needed in those whose diet is high in phytates, such as some vegetarians [308]. These considerations must be balanced against the fact that there is a paucity of adequate zinc biomarkers, and the most widely used indicator, plasma zinc, has poor sensitivity and specificity [312]. Diagnosing zinc deficiency is a persistent challenge [277].

Nearly two billion people in the developing world are deficient in zinc [278]. In children it causes an increase in infection and diarrhea, contributing to the death of about 800,000 children worldwide per year [275]. The World Health Organization advocates zinc supplementation for severe malnutrition and diarrhea [313]. Zinc supplements help prevent disease and reduce mortality, especially among children with low birth weight or stunted growth [313]. However, zinc supplements should not be administered alone, since many in the developing world have several deficiencies, and zinc interacts with other micronutrients [314]. 


\section{Halotherapy}

Salt therapy, halotherapy or speleotherapy [315] is the use of salt mines, caves or other forms of exposure to salt air in the belief that this confers a health benefit. These natural deposits of mineral halite are derived from evaporated ancient lakes and seas. The unrefined rock salt, primarily sodium chloride, also includes varying concentrations of other mineral salts such as calcium and magnesium, manganese and sulfates, which have additional therapeutic properties depending on the source [316]. The special characteristics of the microclimate of a salt mine include stable air temperature, humidity and lack of airborne pollutants such as pollens, and are unique to each mine. At depth the air pressure is also significantly higher than above ground, which has been found to benefit sufferers of respiratory diseases in studies conducted at the Dead Sea, which is below sea level.

There are records of improvements in the breathing of miners in Roman and medieval times. Dr. Felix Boczkowski, a physician at the Polish salt mine at Wieliczka wrote in 1843 that the miners there did not suffer from lung diseases and his successor set up a spa based upon these observations [317]. Modern use of this therapy started in Germany when Dr. Karl Hermann Spannagel [318] noticed improvement in the health of his patients after they hid in the Kluterthöhle karst cave to escape heavy bombing. It is now practiced in places such as Bystrianska in Slovakia [319] Wieliczka in Poland [320], Solotvyno in Ukraine [320] and many other East European countries [321].

Halogenerators are used to simulate the salted atmosphere of salt mines. These highly developed machines crush rock salt into dry micrometer sized particles, ionize the particles, and release them into the air. Salt particles of sizes 0.1-2.5 micrometers are able to escape the natural defenses of the upper airways and travel deep into the lung to the level of the alveoli. Typically used in a small room with floors and walls lined with rock salt, known as artificial salt room.

Salt lamps are another method of salt therapy. A large crystal of natural salt is hollowed out and heated with a tealight or lightbulb. The crystals give off an attractive glow in various colors of pink, orange, red or purple according to the minerals present.

Special home saline therapy devices were developed with the scope of making salt therapy easily available at home, replicating the seashore or speleotherapy aerosol. Hand-held devices and ultrasonic salinizer, use rock salt to create the microscopic breathable particles of salt. The hand-held salt inhaler uses dry rock salt and can deliver the salt aerosol by breathing through the mouth and exhaling through the nose, offering 1-2 hours daily exposure. The ultrasonic salinizer uses saline solution [322] made with natural rock salt, to create the salt aerosol. These salt particles are released into the indoor air and freely breathed during the night, offering 7-8 hours daily exposure, especially for chronic respiratory diseases [323]. Breathing an aerosol of hypertonic salt water $(3-7 \% \mathrm{NaCl})$ has been found effective as a treatment for the heavy build up of mucus typical of cystic fibrosis [323]. The benefits of this treatment were first noticed by sufferers in Australia who were exposed to the natural aerosol of ocean salt spray [323]. 
The use of saline solution delivered by a nebulizer to treat bronchiolitis in children has also been systematically reviewed. The conclusion was current evidence suggests nebulized 3\% saline may significantly reduce the length of hospital stay and improve the clinical severity score in infants with acute viral bronchiolitis [323].

\section{Author details}

Vincent S. Gallicchio

Departments of Biological Sciences and Public Health Sciences, College of Agriculture, Forestry and Life Science and College of Health and Human Development, USA

\section{References}

[1] Kotz J., Treicher P., and Townsend J.R. editors. Chemistry and Chemical Reactivity. Belmont, USA; Thomson Books; p. 351; 2009.

[2] Earths, Metals, Aluminum. Scribd. March, 2013.

[3] Soviet Aluminum from Clay. The New Scientist 1960;191,89.

[4] Dobbs M., editor. Clinical Neurotoxicology: Syndromes, Substances, and Environments, Philadelphia, PA, USA; p. 276-278; 2009.

[5] Kotz J., Treicher P., and Townsend J.R. editors. Chemistry and Chemical Reactivity. Belmont, USA; Thomson Books; p. 979; 2009

[6] Klein C., Hurlburt C., Jr., editors. Manual of Minerology, $20^{\text {th }}$ ed., Wiley, Philadelphia, PA, USA, p. 343-347, 1985.

[7] Zbayolu, G.; Poslu, K. Mining and Processing of Borates in Turkey. Mineral Processing and Extractive Metallurgy Review 9 (1-4) 245-254; 1992.

[8] Crichton, R. R., Biological Inorganic Chemistry: An Introduction. UK. p. 9; 2008.

[9] Krebs R. E., The History and Use of Our Earth's Chemical Elements: A Reference Guide. Greenwood Press. p. 176; 2006.

[10] Fangsen X. Advances in Plant and Animal Boron Nutrition. Dordrecht, Netherlands: Springer. p. 84; 2007.

[11] Lovatt C.J., Bates L.M. Early effects of excess boron on photosynthesis and growth. Journal of Experimental Botany 1984;35 (3) 297-305.

[12] Dickson A.G., Goyet, C. Handbook of method for the analysis of the various parameters of the carbon dioxide system in seawater, version 2. ORNL/CDIAC; 1994:74. 
[13] Tordoff M.G. Calcium: Taste, Intake, and Appetite. Physiological Reviews 2001:81(4): 1567-97.

[14] Dietary Supplement Fact Sheet: Calcium. Office of Dietary Supplements, NIH. Retrieved 31 March 2011.

[15] Standing Committee on the Scientific Evaluation of Dietary Reference Intakes, Food and Nutrition Board, Institute of Medicine. Dietary Reference Intakes for Calcium, Phosphorus, Magnesium, Vitamin D and fluoride. 1997. Washington DC: The National Academies Press.

[16] Committee to Review Dietary Reference Intakes for Vitamin D and Calcium; Institute of Medicine. A. Catharine Ross, Christine L. Taylor, Ann L. Yaktine, Heather B. Del Valle, ed. 2011, Dietary Reference Intakes for Calcium and Vitamin D.

[17] Giovannucci E, Rimm EB, Wolk A, et al. Calcium and fructose intake in relation to risk of prostate cancer. Cancer Research 1998;38(3) 442-7.

[18] Curhan G.C., Willett W.C., Rimm E.B., Stampfer M.J. A prospective study of dietary calcium and other nutrients and the risk of symptomatic kidney stones. The New England Journal of Medicine 1993;328(12) 833-8.

[19] Bihl G., Meyers A. Recurrent renal stone disease-advances in pathogenesis and clinical management. Lancet 2001;358(9282) 651-6.

[20] Hall W.D., Pettinger M., Oberman A. Risk factors for kidney stones in older women in the Southern United States. Am J Med Sci 2001;322(1)12-8.

[21] Schaafsma A., Beelen, G.M. Eggshell powder, a comparable or better source of calcium than purified calcium carbonate: piglet studies. Journal of the Science of Food and Agriculture 1999;79(12) 1596-0.

[22] Schaafsma, A., van Doormaal, J.J., Muskiet, F.A., Hofstede, G.J., Pakan, I., van der Veer E. Positive effects of a chicken eggshell powder-enriched vitamin-mineral supplement on femoral neck bone mineral density in healthy late post-menopausal Dutch women. Br. J. Nutr. 2002;87(3) 267-75.

[23] Rovenský, J., Stancíková, M., Masaryk, P., Svík, K., Istok, R. Eggshell calcium in the prevention and treatment of osteoporosis. Int J Clin Pharmacol Res 2003;23(2-3) 8392.

\section{[24] USDA Nationals Nutrient Database}

[25] Standing Committee on the Scientific Evaluation of Dietary Reference Intakes, Food and Nutrition Board, Institute of Medicine. Dietary Reference Intakes for Calcium, Phosphorus, Magnesium, Vitamin D and fluoride. 1997. Washington DC: The National Academies Press.

[26] Committee to Review Dietary Reference Intakes for Vitamin D and Calcium; Institute of Medicine. A.C. Ross, C. L., Taylor., A.L. Yaktine., H.B. Del Valle., ed. Dietary Ref- 
erence Intakes for Calcium and Vitamin D. 2001. Washington DC: The National Academies Press.

[27] Giovannucci E., Rimm E.B., Wolk A., et al. Calcium and fructose intake in relation to risk of prostate cancer. Cancer Research 1998;58(3): 442-7.

[28] Dawson-Hughes B., Harris S.S., Krall E.A., Dallal G.E. Effect of calcium and vitamin D supplementation on bone density in men and women 65 years of age or older. N. Engl. J. Med. 1997;337(10): 670-6.

[29] Jackson R.D., LaCroix A.Z., Gass M. Calcium plus vitamin D supplementation and the risk of fractures. N. Engl. J. Med. 2006;354(7): 669-83.

[30] Grant A.M., Avenell A., Campbell M.K. Oral vitamin D3 and calcium for secondary prevention of low-trauma fractures in elderly people (Randomised Evaluation of Calcium Or vitamin D, RECORD): a randomised placebo-controlled trial. Lancet 2005;365(9471): 1621-8.

[31] Porthouse J., Cockayne S., King C. Randomised controlled trial of calcium and supplementation with cholecalciferol (vitamin D3) for prevention of fractures in primary care. BMJ 2005;330(7498): 1003-6..

[32] Prince R.L., Devine A., Dhaliwal S.S., Dick I.M. (2006). Effects of calcium supplementation on clinical fracture and bone structure: results of a 5-year, double blind, placebo-controlled trial in elderly women. Arch. Intern. Med. 2006;166(8): 869-75.

[33] Fletcher R.H. Calcium plus Vitamin D plus did not prevent hip fracture or colorectal cancer in postmenopausal woman. ACP J. Club 2006;145(1): 4-5.

[34] Weingarten M.A., Zalmanovici A., Yaphe J. Dietary calcium supplementation for preventing colorectal cancer and adenomatous polyps. In Weingarten, M. A.. Dietary calcium supplementation for preventing colorectal cancer, adenomatous polyps and calcium metabolisism disorder. Cochrane database of systematic reviews (Online) (3): CD003548.

[35] Baron J.A., Beach M., Mandel J.S. (1999). Calcium supplements for the prevention of colorectal adenomas. Calcium Polyp Prevention Study Group. N. Engl. J. Med. 1999;340(2): 101-7.

[36] Bonithon-Kopp C., Kronborg O., Giacosa A., Räth U., Faivre J. Calcium and fibre supplementation in prevention of colorectal adenoma recurrence: a randomised intervention trial. European Cancer Prevention Organisation Study Group. Lancet 2000;356(9238): 1300-6.

[37] Lappe J.M., Travers-Gustafson D., Davies K.M., Recker R.R., Heaney R.P. (2007). Vitamin D and calcium supplementation reduces cancer risk: results of a randomized trial. American Journal of Clinical Nutrition 2007;85(6): 1586-91. 
[38] Wactawski-Wende J., Kotchen J.M., Anderson G.L Calcium plus vitamin D supplementation and the risk of colorectal cancer. N. Engl. J. Med. 2006;354(7): 684-96.

[39] Lappe J.M., Travers-Gustafson D., Davies K.M., Recker R.R., Heaney R.P. Vitamin D and calcium supplementation reduces cancer risk: results of a randomized trial. Am. J. Clin. Nutr. 2007;85(6): 1586-91.

[40] Lin J., Manson J.E., Lee I.M., Cook N.R., Buring J.E., Zhang S.M. Intakes of calcium and vitamin D and breast cancer risk in women. Arch. Intern. Med. 2007;167(10): 1050-9.

[41] Lewis R. J. Sax's Dangerous Properties of Industrial Materials (9 ed.). New York, NY: Van Nostrand Reinhold; 1996. p. 635.

[42] ITII. Toxic and Hazardous Industrial Chemicals Safety Manual. Tokyo, Japan: The International Technical Information Institute. 1988. p. 101

[43] Rumack B.H.. POISINDEX. Information System Micromedex, Inc., Englewood, CO; CCIS Volume 143. Hall A.H., Rumack B.H. (Eds), 2010.

[44] Beall D.P., Henslee H.B., Webb H.R., Scofield R.H. Milk-alkali syndrome: a historical review and description of the modern version of the syndrome. Am. J. Med. Sci. 2006;331(5): 233-42

[45] Picolos M.K., Orlander P.R. Calcium carbonate toxicity: The updated milk-alkali syndrome; report of 3 cases and review of the literature. Endocrine Practice 2005;4(11): 272-80.

[46] Singh, N., Singh P., Hershman J. (2000). Effect of calcium carbonate on the absorption of levothyroxine. JAMA: the Journal of the American Medical Association. 2000;283(21): 2822-2825.

[47] Harding, A. Calcium May Help with Weight Loss. http://www.rxalternativemedicine.com/headline-news.asp (accessed 10 July 2013).

[48] Michaëlsson K., Melhus H., Warensjö-Lemming E., Wolk A., Byberg L, Long term calcium intake and rates of all cause and cardiovascular mortality: community based prospective longitudinal cohort study. BMJ 2013;346:f228.

[49] Xiao Q., Murphy R.A., Houston D.K., Harris T.B., Chow W.H., Park Y. (2013). Dietary and supplemental calcium intake and cardiovascular disease mortality: the National Institutes of Health-AARP diet and health study. JAMA Internal Medicine. 2013;173(8): 639-646.

[50] Mertz W. Chromium in Human Nutrition: A Review. Journal of Nutrition 1993;123 (4): 626-33.

[51] ToxFAQs:Chromium. Agency for Toxic Substances \& Disease Registry. Centers for Disease Control and Prevention. 2001 (accessed July 20, 2013). 
[52] Bona K. R., Love S., Rhodes N. R., McAdory D., Sinha S. H., Kern N., Kent J., Strickland J., Wilson A., Beaird J., Ramage J., Rasco J.F., Vincent J. B. Chromium is not an essential trace element for mammals: Effects of a "low-chromium" diet. JBIC Journal of Biological Inorganic Chemistry 2011;16(3): 381-85.

[53] Anderson R. A. Chromium as an Essential Nutrient for Humans. Regulatory Toxicology and Pharmacology 1997;26(1 Pt 2): S35-S41.

[54] Moukarzel A. Chromium in parenteral nutrition: too little or too much? Gastroenterology 2009;137(5 Suppl): S18-S28.

[55] Vincent J. B. Chromium: Celebrating 50 years as an essential element? Dalton Transactions 2010;39(16): 3787-94.

[56] Cronin J. R. The Chromium Controversy. Alternative and Complementary Therapies 2004;10(1): 39-42.

[57] Stearns D.M. Chromium (III) picolinate produces chromosome damage in Chinese hamster ovary cells. FASEB J. 1995;9(15):1643-8.

[58] Vincent J. B. Recent advances in the nutritional biochemistry of trivalent chromium. Proceedings of the Nutrition Society 2007;63(1): 41-47.

[59] Thor M.Y., Harnack L., King D., Jasthi B., Pettit J. Evaluation of the comprehensiveness and reliability of the chromium composition of foods in the literature. J Food Compost Anal 2011;24(8): 1147-1152.

[60] Kamerud K.L., Hobbie K.A., Anderson K.A. Stainless Steel Leaches Nickel and Chromium into Foods During Cooking. J Agric Food Chem. 2013:61(39): 9495-501

[61] Flint G.N., Packirisamy S. Purity of food cooked in stainless steel utensils. Food Addit Contam 1997;14(2): 115-26.

[62] Dayan A.D., Paine A. J. Mechanisms of chromium toxicity, carcinogenicity and allergenicity: Review of the literature from 1985 to 2000. Human \& Experimental Toxicology 2001;20(9): 439-451.

[63] Newman D. A case of adeno-carcinoma of the left inferior turbinated body, and perforation of thenasal septum, in the person of a worker in chrome pigments. Glasgow Medical Journal 1990;33: 469-70.

[64] Langard S. One Hundred Years of Chromium and Cancer: A Review of Epidemiological Evidence and Selected Case Reports. American Journal of Industrial Medicine 1990;17(2): 189-214.

[65] Cohen M. D., Kargacin B., Klein C. B., Costa M. Mechanisms of chromium carcinogenicity and toxicity. Critical Reviews in Toxicology 1993;23(3): 255-81.

[66] Chrome Contact Allergy. DermNet NZ. http://dermnetnz.org/dermatitis/chrome-allergy.html (accessed 13 December 2013). 
[67] Basketter D., Horev L., Slodovnik D., Merimes S., Trattner A., Ingber A. Investigation of the threshold for allergic reactivity to chromium. Contact Dermatitis 2000;44(2): $70-4$.

[68] Baselt R. C. (2008). Disposition of Toxic Drugs and Chemicals in Man (8th ed.). Foster City: Biomedical Publications. 2008, pp. 305-307.

[69] Johnson M.D., Larry E., ed. Copper. Merck Manual Home Health Handbook. 2008, Merck Sharp \& Dohme Corp., a subsidiary of Merck \& Co., Inc., http://www.merckmanuals.com/404.html (accessed 12 December 2013).

[70] Copper Touch Surfaces. http://www.coppertouchsurfaces.org/antimicrobial/bacteria/ index.html (accessed 12 December 2013.

[71] EPA registers copper-containing alloy products. May 2008. http://www.epa.gov/ pesticides/factsheets/copper-alloy-products.htm (accessed 12 December 2013.

[72] Biurrun A., Caballero L., Pelaz C., León E., Gago A. Treatment of a Legionella pneumophila-Colonized Water Distribution System Using Copper-Silver Ionization and Continuous Chlorination. Infection Control and Hospital Epidemiology 1999;20(6): $426-428$.

[73] Chilean subway protected with Antimicrobial Copper-Rail News. Rail.co. http:// www.rail.com (accessed 12 December 2013)

[74] Codelco to provide antimicrobial copper for new metro lines (Chile). Construpages.com.ve. http://www.construpages.com.ve/nl/noticia_nl.php?

[75] PR 811 Chilean Subway Installs Antimicrobial copper (pdf). Antimicrobialcopper.com

[76] Vest K.E., Hashemi H.F., Cobine P.A. Chapter 13 The Copper Metallome in Eukaryotic Cells. In: Banci L. (Ed.). Metallomics and the Cell. Metal Ions in Life Sciences 2013;12. Springer.

[77] Vest K.E., Hashemi H. F., Cobine P. A. Chapter 12 The Copper Metallome in Prokaryotic Cells. In: Banci L. (Ed.). Metallomics and the Cell. Metal Ions in Life Sciences 2013;12. Springer.

[78] Lippard S.J., Berg J. Principles of bioinorganic chemistry. University Science Books: Mill Valley, CA; 1994.

[79] Decker H., Terwilliger N. COPs and Robbers: Putative evolution of copper oxygenbinding proteins. Journal of Experimental Biology 2000, 203(Pt 12): 1777-1782.

[80] Horseshoe crab. University of Delaware.

[81] Copper. In: Recommended Dietary Allowances. Washington, D.C.: National Research Council, Food Nutrition Board, NRC/NAS. 1980. pp. 151-154.

[82] http://www.copper.org/consumers/health/cu_health_uk.html 
[83] Copper sulfate. http://pmep.cce.cornell.edu/profiles/extoxnet/carbaryl-dicrotophos/ copper-sulfate-ext.html (accessed 18 December 2013)

[84] Adelstein S.J., Vallee B.L. (1961). Copper metabolism in man. New England Journal of Medicine 1961;265(18): 892-97.

[85] Bonham, M. The immune system as a physiological indicator of marginal copper status? British Journal of Nutrition 2002;87(5): 393-403.

[86] Li Y., Trush M., Yager J. DNA damage caused by reactive oxygen species originating from a copper-dependent oxidation of the 2-hydroxy catechol of estradiol. Carcinogenesis 1994;15(7): 1421-27.

[87] Gordon S., John M. Endothelial cell injury due to copper-catalyzed hydrogen peroxide generation from homocysteine

[88] Pesticide Information Profile for Copper Sulfate. Cornell University

[89] Hunt C.E., Carlton W.W. Cardiovascular Lesions Associated with Experimental Copper Deficiency in the Rabbit. Journal of Nutrition 1965;87(4): 385-94.

[90] Ayyat M.S., Marai I.F.M., Alazab A.M. Copper-Protein Nutrition of New Zealand White Rabbits under Egyptian Conditions. World Rabbit Science 1995;3: 113-18.

[91] Kean W.F., Kean I.R.L. Clinical pharmacology of gold. Inflammopharmacology 2008;16(3): 112-25.

[92] Moir, D.M. (1831). Outlines of the ancient history of medicine. (accessed 12 December 2013) http://www.books.google.com

[93] Mortier T. An experimental study on the preparation of gold nanoparticles and their properties, PhD thesis, University of Leuven, May 2006.

[94] Merchant, B. Gold, the Noble Metal and the Paradoxes of its Toxicology. Biologicals 1998;26(1): 49-59.

[95] The healing power of precious metals.

[96] Messori L, Marcon G. "Gold Complexes in the treatment of Rheumatoid Arthritis". In Sigel, Astrid. Metal ions and their complexes in medication. CRC Press. 2004, pp. 280301.

[97] Faulk, W.P., Taylor G.M. An immunocolloid method for the electron microscope. Immunochemistry 1971;8(11): 1081-3.

[98] Roth J., Bendayan M., Orci L. "FITC-protein A-gold complex for light and electron microscopic immunocytochemistry". The journal of histochemistry and cytochemistry: official journal of the Histochemistry Society 1980;28(1): 55-7.

[99] Bozzola J.J., Russell L.D. Electron microscopy: principles and techniques for biologists. Jones \& Bartlett Learning. 1999, p. 65. 
[100] Nanoscience and Nanotechnology in Nanomedicine: Hybrid Nanoparticles in Imaging and Therapy for Prostate Cancer. Radiopharmaceutical Sciences Institute, University of Missouri-Columbia.

[101] Hainfeld J.F., Dilmanian F., Avraham S., Daniel N., Smilowitz H.M. (2008). Radiotherapy enhancement with gold nanoparticles". Journal of Pharmacy and Pharmacology 2008;60(8): 977-85.

[102] McNeil D.G., Jr. In Raising the World's I.Q., the Secret's in the Salt. New York Times, 2006 (accessed 2 December 2013) http://www.nytimes.com/2006/12/16/health/ 16iodine.html?fta=y\&_r=0

[103] U.S. Centers for Disease Control "CDC Radiation Emergencies”, U.S. Centers for Disease Control, U.S. Centers for Disease Control, October 11, 2006 (accessed 3 November 2013) http://www.bt.cdc.gov/radiation/ki.asp

[104] Lancaster J.L. Chapter 4: Physical Determinants of Contrast, in Physics of Medical XRay Imaging. The University of Texas Health Science Center. (accessed 7 November 2013) http://ric.uthscsa.edu/personalpages/lancaster/DI-II_Chapters/DI_chap4.pdf [

[105] Dlouhy A.C., Outten C.E. Chapter 8, The Iron Metallome in Eukaryotic Organisms. In Banci, Lucia (Ed.). Metallomics and the Cell. Metal Ions in Life Sciences 2013;12. Springer.

[106] Lippard S.J., Berg J.M. Principles of Bioinorganic Chemistry. Mill Valley: University Science Books, 1994.

[107] Food Standards Agency-Eat Well, Be Well-Iron Deficiency. Food Standards Agency Eat well, be well - Iron deficiency. Eatwell.gov.uk (accessed 8 October 2013). http:// www.nhs.uk/conditions/Food-poisoning/Pages/Introduction.aspx

[108] Sesink A.L. Red meat and colon cancer: the cytotoxic and hyperproliferative effects of dietary heme. Cancer Research 1999;59(22): 5704-9.

[109] Glei M., Klenow S., Sauer J., Wegewitz U., Richter K., Pool-Zobel B.L. Hemoglobin and hemin induce DNA damage in human colon tumor cells HT29 clone 19A and in primary human colonocytes. Mutat. Res. 2006;594(1-2): 162-171.

[110] Sandhu M.S., White I.R., McPherson K. Systemic Review of the Prospective Cohort Studies on Meat Consumption and Colorectal Cancer Risk: A Meta-Analytical Approach. Cancer Epidemiology, Biomarkers \& Prevention 2001;10(5): 439-46.

[111] Eating Red Meat Will Not Increase Colorectal Cancer Risk, Study Suggests. ScienceDaily. (accessed 6 November 2013) http://www.sciencedaily.com/releases/ 2007/06/070611113729.htm

[112] Hoppe M., Hulthén L., Hallberg L. The relative bioavailability in humans of elemental iron powders for use in food fortification. European Journal of Nutrition 2005; 45(1): 37-44. 
[113] Pineda O., Ashmead H.D. Effectiveness of treatment of iron-deficiency anemia in infants and young children with ferrous bis-glycinate chelate". Nutrition 2001;17(5): $381-4$.

[114] Ashmead H. Conversations on Chelation and Mineral Nutrition. Keats Publishing. 1989

[115] Dietary Reference Intakes: Elements (PDF). The National Academies. 2001. (accessed 5 October 2013) http://www.iom.edu

[116] Iron Deficiency Anemia. MediResource. (accessed 12 October 2013) http://bodyandhealth.canada.com/condition_info_details.asp?disease_id=274

[117] Milman N. Serum ferritin in Danes: studies of iron status from infancy to old age, during blood donation and pregnancy. International Journal of Hematology 1996;63(2): 103-35.

[118] Neilands J.B. Siderophores: structures and function of microbial iron transport compounds. The Journal of Biological Chemistry 1995;270(45): 26723-6.

[119] Neilands J.B. Microbial Iron Compounds. Annual Review of Biochemistry 1981;50:715-31.

[120] Boukhalfa H., Crumbliss A.L. Chemical aspects of siderophore mediated iron transport. BioMetals 2002;15(4): 325-39.

[121] Rouault T.A. How Mammals Acquire and Distribute Iron Needed for Oxygen-Based Metabolism. PLoS Biology 2003;1(1): e9.

[122] Nanami M., Ookawara T., Otaki Y., Ito K., Moriguchi R., Miyagawa K., Hasuike Y., Izumi M., Eguchi H., Suzuki K., Nakanishi T. Tumor necrosis factor-a-induced iron sequestration and oxidative stress in human endothelial cells. Arteriosclerosis, thrombosis, and vascular biology 2005;25(12): 2495-2501.

[123] Ramzi S.C., Vinay K., Tucker C., Stanley L.R. Robbins pathologic basis of disease. Saunders. 1999

[124] Durupt S., Durieu I., Nové-Josserand R., Bencharif L., Rousset H., Vital D.D. Hereditary hemochromatosis. Rev Med Interne 2000;21(11): 961-71.

[125] Brar S., Henderson D., Schenck J., Zimmerman E.A. Iron accumulation in the substantia nigra of patients with Alzheimer's disease and Parkinsonism. Archives of Neurology 2009;66(3): 371-4.

[126] Cheney K., Gumbiner C., Benson B., Tenenbein M. (1995). Survival after a severe iron poisoning treated with intermittent infusions of deferoxamine. J Toxicol Clin Toxicol 1995;33(1): 61-6.

[127] Toxicity, Iron (Medscape) (accessed 3 October 2013) http://emedicine.medscape.com/ article/815213-overview [ 
[128] Tenenbein M. Benefits of parenteral deferoxamine for acute iron poisoning. J Toxicol Clin Toxicol 1996;34(5): 485-489.

[129] Some Facts About Lithium. ENC Laboratories. (accessed 7 October 2013) http:// www.enclabs.com/lithium.html

[130] Anke M., Arnhold W., Groppel B., Krause U. The Biological Importance of Lithium. In Lithium in Biology and Medicine: New Applications and Developments. Eds. G.N. Schrauzer and K.F. Klippel, VCH, Weiheim, 1990, p.147.

[131] Schrauzer G.N., Klippel K.F. Lithum in Biology and Medicine: New Applications and Developments. VCH, Weiheim, 1990, p. 1-209.

[132] Chassard-Bouchaud C., Galle P., Escaig F., Miyawaki M. Bioaccumulation of lithium by marine organisms in European, American, and Asian coastal zones: microanalytic study using secondary ion emission. Comptes rendus de l'Academie des sciences. Serie III, Sciences de la vie 1984;299(18): 719-24.

[133] Schrauzer G.N. Lithium: Occurrence, dietary intakes, nutritional essentiality. Journal of the American College of Nutrition 2002,21(1): 14-21.

[134] Zarse K., Terao T., Tian J., Iwata N., Ishii N., Ristow M. (2011). Low-dose lithium uptake promotes longevity in humans and metazoans. European Journal of Nutrition 2011;50(5): 387-9.

[135] Kean,S. The Disappearing Spoon. 2011. (accessed 3 November 2013) http:// www.theguardian.com/science/2011/nov/10/disappearing-spoon-sam-kean-review

[136] Yacobi S., Ornoy A. Is lithium a real teratogen? What can we conclude from the prospective versus retrospective studies? A review. Isr J Psychiatry Relat Sci 2008;45(2): 95-106.

[137] Gallicchio V.S., Chen M.G. Modulation of murine pluripotential stem cell proliferation in vivo with lithium carbonate. Blood 1980;56(6): 1150-52.

[138] Gallicchio VS. Lithium and the Blood. V.S. Gallicchio (ed.), Kargar. 1991, p. 1-150.

[139] Abundance and form of the most abundant elements in Earth's continental crust. (accessed 2 November 2013) http://www.gly.uga.edu/railsback/Fundamentals/ElementalAbundanceTableP.pdf

[140] Housecroft C.E., Sharpe A.G. Inorganic Chemistry (3rd ed.). 2008. Prentice Hall. p. 305-6.

[141] Ash R. The Top 10 of Everything 2006: The Ultimate Book of Lists. Dk Pub. 2006 (accessed 2 October 2013) http://www.plymouthlibrary.org/faqelements

[142] Anthoni F.J. The Chemical composition of seawater. 2006 (accessed 2 October 2013) http://www.seafriends.org.nz/oceano/seawater.htm 
[143] Euser A.G., Cipolla M. J. Magnesium Sulfate for the Treatment of Eclampsia: A Brief Review. Stroke 2009;40(4): 1169-1175.

[144] Gowariker V., Krishnamurthy V.P., Gowariker S., Dhanorkar M., Paranjape K. The Fertilizer Encyclopedia, p. 224. 2009 p. 224. 2009. (accessed 3 October 2013) http:// books.google.com/books?id=GP1caeWDUWkC\&pg=PA224\# $\mathrm{v}=$ onepage\&q\&f=false

[145] NYU Langone Medical Center. Restless Lee Syndrome. Med.nyu.edu (accessed 4 October 2013) http://www.med.nyu.edu/content?ChunkIID=21806

[146] Magnesium. Ods.od.nih.gov. 2009 (accessed 4 November 2013) http://ods.od.nih.gov/ factsheets/Magnesium-HealthProfessional/

[147] Lack of Energy? Maybe It's Your Magnesium Level. United States Department of Agriculture. 2004. (accessed 4 October 2013) http://www.ars.usda.gov/is/AR/archive/ may04/energy0504.htm?pf=1

[148] University of Maryland Medical Center. Magnesium. 2013 (accessed 3 November 2013) http://umm.edu/health/medical/altmed/supplement/magnesium

[149] University of Maryland. Magnesium. 2013. (accessed 7 May 2013) http://umm.edu/ health/medical/altmed/supplement/magnesium

[150] Larsson S.C., Virtanen M.J., Mars M., Männistö S., Pietinen P., Albanes D., Virtamo J. "Magnesium, calcium, potassium, and sodium intakes and risk of stroke in male smokers". Arch. Intern. Med. 2008;168(5): 459-65.

[151] Dietary Supplemental Fact Sheet-Magnesium. US National Institute of Health. 2013 (accessed 2 October 2013) http://ods.od.nih.gov/factsheets/Magnesium-HealthProfessional/

[152] Magnesium. University of Maryland Medical Center". 2013 (accessed 3 November 2013) http://umm.edu/health/medical/altmed/supplement/magnesium.

[153] Wester P.O. Magnesium. Am. J. Clin. Nutr. 1987;45 5 Suppl): 1305-12.

[154] Arnaud M.J. Update on the assessment of magnesium status". Br. J. Nutr. 2008;99 Suppl 3: S24-36.

[155] Rob P.M., Dick K., Bley N., Seyfert T., Brinckmann C., Höllriegel V., Friedrich H.J., Dibbelt L., Seelig M.S. (1999). Can one really measure magnesium deficiency using the short-term magnesium loading test? J. Intern. Med. 1999;246(4): 373-378.

[156] Franz K.B. A functional biological marker is needed for diagnosing magnesium deficiency. J Am Coll Nutr 2004;23(6): 738S-41S.

[157] Vitamins and minerals-others-NHS Choices. Nhs.uk. 2012 (accessed 9 October 2013) http://www.nhs.uk/Conditions/vitamins-minerals/Pages/Other-vitamins-minerals.aspx 
[158] Dietary Supplement Fact Sheet: Magnesium. Office of Dietary Supplements. 2012 (accessed 3 October 2013) http://ods.od.nih.gov/factsheets/Magnesium-HealthProfessional/

[159] Firoz M, Graber M. Bioavailability of US commercial magnesium preparations. Magnes Res 2001;14(4): 257-62.

[160] Lindberg J.S., Zobitz M.M., Poindexter J.R., Pak C.Y. Magnesium bioavailability from magnesium citrate and magnesium oxide. J Am Coll Nutr 1990:9(1): 48-55.

[161] Walker A.F., Marakis G., Christie S., Byng M. Magnes Res 2003;16(3): 183-91.

[162] Kontani M., Hara A., Ohta S., Ikeda T. Hypermagnesemia induced by massive cathartic ingestion in an elderly woman without pre-existing renal dysfunction. Intern. Med. 2005;44(5): 448-452.

[163] Giannini, A. J. Drugs of Abuse (Second ed.). Los Angeles: Physicians Management Information Co. 1997.

[164] Baselt R., Disposition of Toxic Drugs and Chemicals in Man, 8th edition, Biomedical Publications, Foster City, CA, 2008.

[165] Eby G. $3^{\text {rd }}$., Eby K.L Magnesium for treatment-resistant depression: a review and hypothesis. Medical hypotheses 2010;74(4): 649-660.

[166] Barragán-Rodríguez L., Rodríguez-Morán M., Guerrero-Romero F. Efficacy and safety of oral magnesium supplementation in the treatment of depression in the elderly with type 2 diabetes: a randomized, equivalent trial. Magnesium research: official organ of the International Society for the Development of Research on Magnesium 2008;21(4): 218-23.

[167] Jee S.H., Miller E.R. $3^{\text {rd }}$., Guallar E., Singh V.K., Appel L.J., Klag M.J. The effect of magnesium supplementation on blood pressure: a meta-analysis of randomized clinical trials. Am J Hypertens 2002;15(8): 691-696.

[168] Geiger H., Wanner C. Magnesium in Disease. Clin Kidney J 2012;5 (Suppl 1): i25-i38.

[169] Guerrero-Romero F., Rodriguez-Moran M. Low serum magnesium levels and metabolic syndrome. Acta Diabetol 2002;39(4): 209-213.

[170] Zipes D.P., Camm A.J., Borggrefe M. et al. (2012). ACC/AHA/ESC 2006 Guidelines for Management of Patients with Ventricular Arrhythmias and the Prevention of Sudden Cardiac Death: a report of the American College of Cardiology / American Heart Association Task Force and the European Society of Cardiology Committee for Practice Guidelines (writing committee to develop Guidelines for Management of Patients with Ventricular Arrhythmias and the Prevention of Sudden Cardiac Death): developed in collaboration with the European Heart Rhythm Association and the Heart Rhythm Society. Circulation 2012;114(10): e385-e484. 
[171] James M.F. Magnesium in obstetrics. Best Pract Res Clin Obstet Gynaecol. 2010;24(3): 327-337.

[172] Hashimoto T., Hara A., Ohkubo T., Kikuya M., Shintani Y., Metoki H., Inoue R., Asayama K., Kanno A., Nakashita M., Terata S., Obara T., Hirose T., Hoshi H., Totsune K, Satoh H, Imai Y (2010). "Serum magnesium, ambulatory blood pressure, and carotid artery alteration: the Ohasama study". Am J Hypertens 2010;23(12): 1292-1298.

[173] Massy Z.A., Drüeke T.B. Magnesium and outcomes in patients with chronic kidney disease: focus on vascular calcification, atherosclerosis, and survival. Clin Kidney J 2012;5 (Suppl 1): i52-i61.

[174] Turgut F., Kanbay M., Metin M.R., Uz E., Akcay A., Covic A. Magnesium supplementation helps to improve carotid intima media thickness in patients on hemodialysis. Int Urol Nephrol 2008;40(4): 1075-1082.

[175] Passlick-Deetjen J., Wang W. et al. Magnesium and mortality risk in hemodialysis patients. European Renal Association (ERA) and European Dialysis and Transplant Association (EDTA 2010), XLVII Congress, 25-28 June, Munich, Germany. Oral presentation.

[176] Shimura E., Okuno S., Yamakawa T., Inaba M., Nishizawa Y. Serum magnesium concentration is a significant predictor of mortality in maintenance hemodialysis patients. Magnes Res 2007;20(4): 237-244.

[177] Science Safety: Chapter 8. Government of Manitoba, 2007. (accessed 2 October 2013) http://www.edu.gov.mb.ca

[178] Roth, J., Ponzoni S., Aschner M. Chapter 6 Manganese Homeostasis and Transport. In Banci, Lucia (Ed.). Metallomics and the Cell. Metal Ions in Life Sciences 2013;12. Springer.

[179] Emsley J. Manganese. Nature's Building Blocks: An A-Z Guide to the Elements. Oxford, UK: Oxford University Press. 2001. p. 249-53, 2001.

[180] Law N., Caudle M., Pecoraro V. Manganese Redox Enzymes and Model Systems: Properties, Structures, and Reactivity. Advances in Inorganic Chemistry 1998;46. p. 305.

[181] Takeda, A. Manganese action in brain function. Brain Research Reviews 2003;41(1): 79-87.

[182] Dismukes G.C., Willigen R. T. van. Manganese: The Oxygen-Evolving Complex \& Models. "Manganese: The Oxygen-Evolving Complex \& Models". Encyclopedia of Inorganic Chemistry, 2006.

[183] Hasan H. Manganese. The Rosen Publishing Group. p. 31., 2008.

[184] Manganese Chemical Background. Metcalf Institute for Marine and Environmental Reporting University of Rhode Island, 2006. 
[185] Risk Assessment Information System Toxicity Summary for Manganese. Oak Ridge National Laboratory. 2008.

[186] Ong K.L., Tan T.H., Cheung W.L. Potassium permanganate poisoning - a rare cause of fatal self poisoning. Emergency Medicine Journal 1997;14: 43-5.

[187] Young R., Critchley J.A., Young K.K., Freebairn R.C., Reynolds A.P., Lolin Y.I. Fatal acute hepatorenal failure following potassium permanganate ingestion. Human \& Experimental Toxicology 1996;15(3): 259-61.

[188] Elsner R.J.F., Spangler J.G. Neurotoxicity of inhaled manganese: Public health danger in the shower? Medical Hypotheses 2005;65(3): 607-616.

[189] Safety and Health Topics: Manganese Compounds (as Mn). (accessed 2 October 2013) http://www.osha.gov

[190] Yin Z., Jiang H., Lee E.S., Ni M., Erikson K.M., Milatovic D., Bowman A.B., Aschner $\mathrm{M}$. Ferroprotein is a manganese-responsive protein that decreases manganese cytotoxicity and accumulation. Journal of Neurochemistry 2010;112(5): 1190-8.

[191] Bouchard M.F., Sébastien S., Benoit B., Melissa L., Marie-Ève B., Thérèse B., Elyse L., David C. B., Donna M. Intellectual Impairment Impairment in School-Age in SchoolAge Children. Environmental Health Perspectives 2010;119(1): 138-143.

[192] Finley, J.W., Davis, C.D. (1999). Manganese deficiency and toxicity: Are high or low dietary amounts of manganese cause for concern? BioFactors 1999;10(1): 15-24.

[193] Barceloux D., Barceloux D. Manganese. Clinical Toxicology 1999;37(2): 293.

[194] Baselt R. Disposition of Toxic Drugs and Chemicals in Man, 8th edition, Biomedical Publications, Foster City, CA, 2008, pp. 883-86.

[195] Normandin L., Hazell A.S. Manganese neurotoxicity: an update of pathophysiologic mechanisms. Metabolic Brain Disease 2002;17(4): 375-87.

[196] Couper J. On the effects of black oxide of manganese when inhaled into the lungs. $B r$. Ann. Med. Pharm. Vital. Stat. Gen. Sci. 1837;1: 41-2.

[197] Cersosimo M.G., Koller W.C. The diagnosis of manganese-induced parkinsonism. NeuroToxicology 2007;27(3): 340-46.

[198] Platinum (pt). Encyclopædia Britannica Online. Encyclopædia Britannica Inc., 2012. (accessed 24 October 2013) http://www.britannica.com

[199] Harper, Douglas. "platinum". Online Etymology Dictionary. (accessed 26 October 2013) http://www.on_line_etymology_dictionary [

[200] Lagowski J.J., ed. Chemistry Foundations and Applications 3. Thomson Gale. 2004. pp. 267-68. 
[201] Wheate N.J., Walker S., Craig G.E., Oun R. The status of platinum anticancer drugs in the clinic and in clinical trials. Dalton transactions (Cambridge, England : 2003), 2010;39(35): 8113-27.

[202] Krebs R.E. Platinum. The History and Use of our Earth's Chemical Elements. Greenwood Press. 1998. p. 124-27.

[203] CRC contributors. Platinum. In Lide, David R. CRC Handbook of Chemistry and Physics 4. New York: CRC Press. 2007-2008. p. 26.

[204] Occupational Health Guideline for Soluble Platinum Salts (as Platinum). Centers for Disease Control and Prevention. (accessed 9 October 2013) http://www.cdc.gov/ niosh/docs

[205] Occupational Health Guideline for Soluble Platinum Salts (as Platinum). (accessed 23 October 2013) http://www. cdc.gov/niosh/docs/81-123

[206] FDA Backgrounder on Platinum in Silicone Breast Implants. U.S. Food and Drug Administration. Archived from the original on 2008. (accessed 24 October 2013) http:// www.fda.gov/cdrh/breastimplants/platinum.html

[207] Brook M. Platinum in silicone breast implants. Biomaterials 2006;27(17): 3274-86.

[208] Haynes W.M., ed. CRC Handbook of Chemistry and Physics (92nd ed.). 2011 CRC Press. p. 4.122.

[209] Abdel-Wahab M., Youssef S., Aly A., el-Fiki S., el-Enany N., Abbas M. A simple calibration of a whole-body counter for the measurement of total body potassium in humans. International Journal of Radiation Applications and Instrumentation. Part A. Applied Radiation and Isotopes 1992;43(10): 1285-89.

[210] Chang R. Chemistry. McGraw-Hill Higher Education. 2007. p. 52.

[211] Campbell N. Biology. Menlo Park, California: Benjamin/Cummings Pub. Co. 1987. p. 795.

[212] Hellgren M, Sandberg L., Edholm O. A comparison between two prokaryotic potassium channels ( $\mathrm{K}_{\mathrm{ir}}$ Bac1.1 and $\mathrm{KcsA}$ ) in a molecular dynamics (MD) simulation study. Biophysical Chemistry 2006;120(1): 1-9.

[213] Institute of Medicine (U.S.). Committee on Optimization of Nutrient Composition of Military Rations for Short-Term, High-Stress Situations; Institute of Medicine (U.S.). Committee on Military Nutrition Research. Nutrient Composition of Rations for Short-Term, High-Intensity Combat Operations. National Academies Press. 2006. p. 287.

[214] Shallenberger R.S. Taste Chemistry. Springer. 1993. p. 120.

[215] Lockless S.W., Zhou M., MacKinnon R. Structural and thermodynamic properties of selective ion binding in a K+channel. PLoS Biol 2007;5(5): e121. 
[216] Slonim A.D., Pollack M.M. Potassium. Pediatric critical care medicine. Lippincott Williams \& Wilkins. 2006. p. 812.

[217] Visveswaran K. (2009). Hypokalemia. Essentials of Nephrology (2nd ed.). BI Publications. 2009; p. 257.

[218] Potts W.T.W., Parry G. Osmotic and ionic regulation in animals. Pergamon Press. 1964.

[219] Lans H.S., Stein I. F., Meyer K.A. (1952). The relation of serum potassium to erythrocyte potassium in normal subjects and patients with potassium deficiency. American Journal of Medical Science 1952;223(1): 65-74.

[220] Bennett C.M., Brenner B.M., Berliner R.W. Micropuncture study of nephron function in the rhesus monkey. Journal of Clinical Investigation 1968;47 (1): 203-216.

[221] Solomon A.K. Pumps in the living cell. Scientific American 1962;207(2): 100-8.

[222] Kernan R.P. Cell potassium (Transport in the life sciences). New York: Wiley. 1980. p. $40-8$.

[223] Squires R.D., Huth E.J. Experimental potassium depletion in normal human subjects. I. Relation of ionic intakes to the renal conservation of potassium. Journal of Clinical Investigation 1959;38(7): 1134-48.

[224] Fiebach N.H., Barker L.R., Burton J.R., Zieve P.D. Principles of Ambulatory Medicine. Lippincott Williams \& Wilkins. 2007. p. 748-50.

[225] Gadsby D.C. Ion transport: spot the difference. Nature 2004;427(6977): 795-97.

[226] Jiang Y., Lee A., Chen J., Cadene M., Chait B.T., MacKinnon R. Crystal structure and mechanism of a calcium-gated potassium channel. Nature 2002;417 6888): 515-22.

[227] Shi N., Ye S., Alam A., Chen L., Jiang Y. Atomic structure of a $\mathrm{Na}^{+}$-and $\mathrm{K}^{+}$-conducting channel. Nature 2006;440(7083): 570-74.

[228] Zhou Y., Morais-Cabral J.H., Kaufman A., MacKinnon R. Chemistry of ion coordination and hydration revealed by a $\mathrm{K}^{+}$channel-Fab complex at 2.0 A resolution. Nature 2001;414(6859): 43-8.

[229] Noskov S.Y., Bernèche S., Roux B. Control of ion selectivity in potassium channels by electrostatic and dynamic properties of carbonyl ligands. Nature 2004;431(7010): 830 834.

[230] Potassium Food Charts. Asia Pacific Journal of Clinical Nutrition. (accessed 25 October 2013). http://www.apjen.nhri.org.tw/server/info

[231] Folis R.H.Myocardial Necrosis in Rats on a Potassium Low Diet Prevented by Thiamine Deficiency. Bull. Johns-Hopkins Hospital 1942;71: 235. 
[232] DRI, Dietary Reference Intakes for Water, Potassium, Sodium, Chloride, and Sulfate. Washington, D.C.: National Academies Press. 2001. (accessed 24 October 2013) http:// www.nap.edu/openbook.php?isbn=0309091691

[233] Grim C.E., Luft F.C., Miller J.Z., Meneely G.R., Battarbee H.D., Hames C.G., Dahl L.K. Racial differences in blood pressure in Evans County, Georgia: relationship to sodium and potassium intake and plasma renin activity. Journal of Chronicle Diseases 1980;33(2): 87-94.

[234] Karger S. Energy and nutrient intake in the European Union. Annals of Nutrition and Metabolism 2004;48 2 (suppl): 1-16.

[235] D'Elia L., Barba G., Cappuccio F., Strazzullo P. Potassium Intake, Stroke, and Cardiovascular Disease: A Meta-Analysis of Prospective Studies. The Journal of the American College of Cardiology 2011;57(10): 1210-19.

[236] Ruyle G. Poisonous Plants on Arizona Rangelands. (2009). The University of Arizona. (accessed 30 October 2013) http://www.cals.arizona/edu/arec/pubs

[237] Linus Pauling Institute at Oregon State University. (accessed 2 November 2013) http://www.lpi.oregonstate.edu/infocenter/minerals/selenium

[238] "Selenium". Linus Pauling Institute at Oregon State University. (accessed 2 November 2013) http://www.lpi.oregonstate.edu/infocenter/minerals/selenium

[239] Mazokopakis E.E., Papadakis J.A., Papadomanolaki M.G., Batistakis A.G., Giannakopoulos T.G., Protopapadakis E.E., Ganotakis E.S. Effects of 12 months treatment with L-selenomethionine on serum anti-TPO Levels in Patients with Hashimoto's thyroiditis. Thyroid: official journal of the American Thyroid Association 2007;17(7): 60912.

[240] Ralston N.V., Ralston C.R., Blackwell J.L. $3^{\text {rd }}$., Raymond L.J. Dietary and tissue selenium in relation to methylmercury toxicity. Neurotoxicology 2008;29 (5): 802-11.

[241] Ralston N.V.C., Raymond L.J. Dietary selenium's protective effects against methylmercury toxicity. Toxicology 2010;278(1): 112-123.

[242] Carvalho C.M.L., Chew H.S.I.,; Hashemy J., Lu A., Holmgren A. Inhibition of the human thioredoxin system: A molecular mechanism of mercury toxicity. Journal of Biological Chemistry 2008;283(18): 11913-11923.

[243] Gladyshev V.N., Hatfield D.L. Selenocysteine-containing proteins in mammals. Journal of Biomedical Science 1999;6(3): 151-160.

[244] Stadtman T.C. Selenocysteine. Annual Review of Biochemistry 1996;65: 83-100.

[245] Schroeder H.A., Frost D.V., Balassa J.J. Essential trace metals in man: Selenium. Journal of chronic diseases 1970;23(4): 227-43. 
[246] Selenium (IV) Sulfide. Pharmacy Codes. (accessed 23 November 2013) http:// www.pharmacycode.com/selenium_sulfide.html

[247] Selenium sulfide. DermNetzNZ. 2009 (accessed 23 November 2013) http:// www.dermnetnz.org/treatments/selenium.html

[248] Baselt R. Disposition of Toxic Drugs and Chemicals in Man (8 ed.). Foster City, CA: Biomedical Publications. 2008. p. 1416-20.

[249] Brain P., Cousens R. Weed Research. Weed Research 1989;29(2): 93-6.

[250] Ravaglia G., Forti P., Maioli F., Bastagli L., Facchini A., Mariani E., Savarino., Sassi S., Cucinotta D., Lenaz G. Effect of micronutrient status on natural killer cell immune function in healthy free-living subjects aged $>=90 y 1$. American Journal of Clinical Nutrition 2000;71 (2): 590-598.

[251] MedSafe Editorial Team. Selenium. (2009) Prescriber Update Articles. New Zealand Medicines and Medical Devices Safety Authority.. (accessed 24 November 2013) http://www.medsafe.govt.nz/profs/puarticles/sel.htm

[252] Ralston N.V.C., Raymond L.J. Dietary selenium's protective effects against methylmercury toxicity. Toxicology 2010;278(1): 112-123.

[253] Mann J., Truswell A.S. Essentials of Human Nutrition (2nd ed.). Oxford University Press. 2002.

[254] Moreno-Reyes R., Mathieu F., Boelaert M., Begaux F., Suetens C., Rivera M.T., Nève J., Perlmutter N., Vanderpas J. Selenium and iodine supplementation of rural Tibetan children affected by Kashin-Beck osteoarthropathy. American Journal of Clinical Nutrition 2003;78(1): 137-144.

[255] Kachuee R., Moeini M., Suori M. The effect of dietary organic and inorganic selenium supllmentation on serum Se, Cu, Fe and $\mathrm{Zn}$ status during the late in Merghoz goats and their kids. Small Ruminant Research 2013;110(1). pp. 20-7.

[256] National Research Council, Subcommittee on Sheep Nutrition. Nutrient requirements of sheep. 6th ed., National Academy Press, Washington, 1985.

[257] National Research Council, Committee on Nutrient Requirements of Small Ruminants. Nutrient requirements of small ruminants. National Academies Press, Washington. 2007.

[258] Coop I.E., Blakely R.L. The metabolism and toxicity of cyanides and cyanogenic glycosides in sheep. N. Z. J. Sci. Technol. 1949;30: 277-91.

[259] Kraus R.J., Prohaska J.R., Ganther H.E. (1980). "Oxidized forms of ovine erythrocyte glutathione peroxidase. Cyanide inhibition of 4-glutathione:4-selenoenzyme". Biochem. Biophys. Acta 1980;615(1): 19-26. 
[260] Kahn C.M., (ed.). Merck veterinary manual. 9th ed. Merck \& Co., Inc., 2005. Whitehouse Station.

[261] Ip C. Lessons learned from basic research in selenium and cancer prevention. The Journal of Nutrition. 1998;128(11): 1845-54.

[262] Rayman M.P. The importance of selenium to human health. The Lancet 2000;356(9225): 233-41.

[263] Bjelakovic G., Nikolova D., Gluud L.L., Simonetti R.G., Gluud C. Antioxidant supplements for prevention of mortality in healthy participants and patients with various diseases. In Bjelakovic G.. Cochrane database of systematic reviews (Online) 2012;3: CD007176. http://summaries.cochrane.org/CD007176/antioxidant-supplements-forprevention-of-mortality-in-healthy-participants-and-patients-with-various-diseases

[264] Sodium and Potassium Quick Health Facts. health.ltgovernors.com. (accessed 30 November 2013) http://www.health.itgovernors.com

[265] Dietary Reference Intakes: Water, Potassium, Sodium, Chloride, Sulfate. Food and Nutrition Board, Institute of Medicine, United States National Academies. (2004). (accessed 30 November 2013) http://www.iom.edu/reports/2004.

[266] U.S. Department of Agriculture; U.S. Department of Health and Human Services (2010) Dietary Guidelines for Americans.. (accessed 30 November 2013) http:// www.usda.gov/human

[267] Geleijnse J.M., Kok F.J., Grobbee D.E.(2004). Impact of dietary and lifestyle factors on the prevalence of hypertension in Western populations. European Journal of Public Health 2004;14(3): 235-39.

[268] Lawes C.M., Vander Hoorn S., Rodgers A. International Society of Hypertension (2008). Global burden of blood-pressure-related disease, 2001. Lancet 371 (9623): 1513-18.

[269] McGuire M., Beerman K.A. Nutritional Sciences: From Fundamentals to Food. Cengage Learning. p. 546. 2011.

[270] Campbell N. Biology. Benjamin/Cummings. 1987. p. 795.

[271] Srilakshmi B. Nutrition Science (2nd ed.). New Age International. 2006. p. 318. (accessed 30 November 2013) http://www.books.google.com

[272] Kering M.K. (2008). "Manganese Nutrition and Photosynthesis in NAD-malic enzyme C4 plants Ph.D. dissertation". University of Missouri-Columbia. 2008. (accessed 30 November 2013) http://www.mospace.umsystem.edu/xmlui/bitstream/handle/ $10355 / 7201$

[273] Subbarao G.V., Ito O., Berry W.L., Wheeler R.M. Sodium-A Functional Plant Nutrient. Critical Reviews in Plant Sciences 2003;22(5): 391-416. 
[274] Zhu J.K. Plant salt tolerance. Trends in Plant Science. 2001;6(2): 66-71.

[275] Plants and salt ion toxicity. Plant Biology. (accessed 30 November 2013). http:// www.plant-biology.com/salt-ion-toxicity.php

[276] Angelici R.J. Synthesis and Technique in Inorganic Chemistry. Mill Valley, CA: University Science Books. 1999.

[277] Zinc. (accessed 30 November 2013) http://www.infinityfoundation.com/mandala/ t_est/t_es_agraw_zinc_frameset.htm

[278] Zinc. (accessed 30 November 2013) http://www.ancient-asia-journal.com/article/ view/aa.

[279] Hambidge K.M., Krebs N.F. Zinc deficiency: a special challenge. J. Nutr. 2007;137(4): 1101-5.

[280] Walker J.C.F. Primary Wood Processing: Principles and Practice. Springer. 2006. p. 317.

[281] ZDDP Engine Oil-The Zinc Factor. Mustang Monthly. (accessed 30 November 2013) http://www.mustangmonthly.com/techarticles

[282] DiSilvestro R.A. Handbook of Minerals as Nutritional Supplements. CRC Press. 2004. p. 135, 155.

[283] Milbury P.E., Richer A.C. Understanding the Antioxidant Controversy: Scrutinizing the "fountain of Youth". Greenwood Publishing Group. 2008. p. 99.

[284] Keen C.L., Gershwin M.E. Zinc deficiency and immune function. Annual review of nutrition 1990;10: 415-31.

[285] Bhutta Z.A., Bird S.M., Black R.E., Brown K.H., Gardner J.M., Hidayat A., Khatun F., Martorell R. (2000). Therapeutic effects of oral zinc in acute and persistent diarrhea in children in developing countries: pooled analysis of randomized controlled trials. The American journal of clinical nutrition 2000;72(6): 1516-22.

[286] Age-Related Eye Disease Study Research Group (2001). A Randomized, Placebo, Placebo-Controlled, Clinical Trial of High-Dose Supplementation with Vitamins C and E, Beta Carotene, and Zinc for Age-Related Macular Degeneration and Vision Loss: AREDS Report No. 8. Arch Ophthalmology 2001;119(10): 1417-36.

[287] Bodsworth C.The Extraction and Refining of Metals. CRC Press. 1994. p. 148.

[288] Valko M., Morris H., Cronin M.T.D. Metals, Toxicity and Oxidative Stress. Current Medicinal Chemistry. 2005;12 (10): 1161-208.

[289] Venkatratnam A., Nathan L. Zinc Reduces the Detection of Cocaine, Methamphetamine, and THC by ELISA Urine Testing. Journal of Analytical Toxicology 2011;35(6): 333-40. 
[290] Shah M., Christopher K., Nathan H., Lents M.K. Hoyer, Nimah J., Claudette K., Baldassare J.J. Direct intra-tumoral injection of zinc-acetate halts tumor growth in a xenograft model of prostate cancer. Journal of Experimental and Clinical Cancer Research 2005;28(84): 84.

[291] Leitzmann M.F., Stampfer M.J., Wu K., Colditz G.A., Willett W.C., Giovannucci E.L. Zinc Supplement Use and Risk of Prostate Cancer. JNCI Journal of the National Cancer Institute 2003;95(13):1004.

[292] World's Oldest Pills Treated Sore Eyes World's oldest pills treated sore eyes". New Scientist. 7 January 2013. (accessed 5 December 2013) http://www.newsscientist.com/ article/dn23049-worlds-oldest-pills-treated-sore-eyes.html

[293] Eby G. Zinc lozenges: cold cure or candy? Solution chemistry determinations. Bioscience Reports 2004;24(1): 23.

[294] Eby G. (2010). Zinc lozenges as cure for the common cold-a review and hypothesis. Medical Hypotheses 2010;74(3): 482.

[295] Gupta C.K., Mukherjee T.K. Hydrometallurgy in Extraction Processes. CRC Press. 1990. p. 62.

[296] Frankland-Duppa Reaction. 2012. (accessed 2 December 2013). http://www.drugfuture.com/organicamereactions/onr144.tm

[297] Kim J.G., Walsh P.J. From Aryl Bromides to Enantioenriched Benzylic Alcohols in a Single Flask: Catalytic Asymmetric Arylation of Aldehydes". Angewandte Chemie International Edition 2006;45 25): 4175.

[298] Wapnir, Raul A. (1990). Protein Nutrition and Mineral Absorption. Boca Raton, Florida: CRC Press. ISBN 0-8493-5227-4.

[299] Prasad A.S. Zinc in Human Health: Effect of Zinc on Immune Cells. Mol. Med. 2008;14(5-6): 353-7.

[300] Sugarman B. Zinc and infection. Review of Infectious Diseases 1983;5(1): 137-47.

[301] NRC 2000, p. 443 (accessed 3 December 2013) http://www.epa.gov/ncer/publications/ workshop/pdf/howarth.

[302] Cotton 1999, pp. 625-629 (accessed 3 December 2013) http://.www.ag.arizona.edu/ pubs/crops/az1170/az11706a

[303] Brandt E.G., Hellgren M., Brinck T., Bergman T., Edholm O. Molecular dynamics study of zinc binding to cysteines in a peptide mimic of the alcohol dehydrogenase structural zinc site. Phys. Chem. Chem. Phys. 2009;11(6): 975-83.

[304] Rink L. Gabriel P. Zinc and the immune system. Proc Nutr Soc 2000;59(4): 541-52.

[305] National Agricultural Library. Nal.usda.gov. 2011. (accessed 3 November 2013). http://www.nal.usda.gov/ 
[306] Wapnir R. A. Protein Nutrition and Mineral Absorption. Boca Raton, Florida: 1990. CRC Press.

[307] Gadallah M.A.A. Effects of indole-3-acetic acid and zinc on the growth, osmotic potential and soluble carbon and nitrogen components of soybean plants growing under water deficit. Journal of Arid Environments 2000;44(4): 451.

[308] Zinc-Summary. Dietary Reference Intakes for Vitamin A, Vitamin K, Arsenic, Boron, Chromium, Copper, Iodine, Iron, Manganese, Molybdenum, Nickel, Silicon, Vanadium, and Zinc (2001). Institute of Medicine, Food and Nutrition Board. (accessed 3 November 2013). http://www.books.nap.edu/openbook.php

[309] Blew J.O. Wood Preservatives. Department of Agriculture, Forest Service, Forest Products Laboratory. 1953. (accessed 3 November 2013) http://www.ir.library/ oregonstate.edu/xmlui/bitstream/handle/1957/816

[310] Rosado J.L. Zinc and copper: proposed fortification levels and recommended zinc compounds. Journal of Nutrition. 2003;133(9): 2985S-9S.

[311] Hotz C., DeHaene J., Woodhouse L.R., Villalpando S., Rivera J.A., King J.C. Zinc absorption from zinc oxide, zinc sulfate, zinc oxide+EDTA, or sodium-zinc EDTA does not differ when added as fortificants to maize tortillas. Journal of Nutrition 2005;135(5): 1102-5.

[312] Barrie S.A., Wright J.V., Pizzorno J.E., Kutter E., Barron P.C. Comparative absorption of zinc picolinate, zinc citrate and zinc gluconate in humans. Agents Actions 1987;21(1-2): 223-8.

[313] DiSilvestro R.A., Swan M. Comparison of Four Commerically Available Zinc Supplements for Performance in a Zinc Tolerance Test. The FASEB Journal. 2008;22: 693.3.

[314] Ibs K.H., Rink L. Zinc-altered immune function. Journal of Nutrition 2003;133 5 Suppl 1): 1452S-6S.

[315] Parfitt T. Ukrainian salt mines reinvented as a haven for asthma sufferers. The Guardian. 2005. (accessed 4 November 2013) http://www.guardian.co.uk/world/ 2005/dec/03

[316] Beamon S.P., Falkenbach A., Fainburg G., Linde K. Speleotherapy for asthma. Speleotherapy for asthma, Cochrane Summaries, October 7, 2009. (accessed 6 November 2013) http://www.summaries.cochrane.org/cd0017471/speleotherapy-for-asthma

[317] Valjent R. Caves offer asthma relief for tourists. The Slovak Spectator 2007. (accessed 7 November 2013) http://www.spectator.sk/articles/view/27566/3

[318] Skulimowski M.M. The microclimatic effect of the subterranean chambers of the Wieliczka Salt Mine in the treatment of bronchial asthma. Annals of Allergy 1968;26(2): 66-9. 
[319] Fawkes H. Ukrainian mine helps asthmatics. BBC. 2006. (accessed 3 November 2013) http://www.news.bbc.co.uk/1/hi/world/europe/457388.htm

[320] Simionca I., Jaroslav C., Slavic P., Hoteteu O.M.M., Enache L., Stoian G. (2012). The XIVth International Symposium of Speleotherapy. (accessed 6 November 2013) http://www.salinetherapy.com/wp-uploads/2013/03/abstracts_of_ the_xiv_th_international_symposium_of_speleotherapy_turda_rom_ania_2012

[321] Zhang L., Mendoza-Sassi R., Wainwright C.A., Klassen T.P (2008), Nebulized hypertonic saline solution for acute bronchiolitis in infants., in Zhang, Linjie, The Cochrane Database of Systematic Reviews (John Wiley) 2008.(4): CD006458, (accessed 7 November 2013) http://www.mrw.interscience.wiley.com/cochrane/cisysrev/articles/cd006458

[322] Wark P., McDonald V.M. Nebulised hypertonic saline for cystic fibrosis. Cochrane Database of Systematic Reviews 2009, Issue 2. Art. No.: CD001506.

[323] Elliott J. Dose of salts to ease cystic fibrosis. BBC. 2006. (accessed 7 November 2013) http://www.news.bbc.co.uk/health/4700408.htm 
